\title{
Oxaazabicyclooctene Oxides, Another Type of Bridgehead Nitrones: Diastereoselective Assembly from Acetylene gas, Ketones and Hydroxyl Amine
}

\author{
Elena Yu. Schmidt, Inna V. Tatarinova, Igor' A. Ushakov, Alexander V. Vashchenko, \\ and Boris A. Trofimov*
}

A. E. Favorsky Irkutsk Institute of Chemistry,Siberian Branch, Russian Academy of Sciences, 1 Favorsky Str., 664033 Irkutsk, Russia

E-mail: boris_trofimov@irioch.irk.ru

\section{Table of Contents}

$\begin{array}{ll}\text { 1. NMR spectra } & \text { S2 }\end{array}$

$\begin{array}{ll}\text { 2. X-Ray diffraction analysis } & \text { S28 }\end{array}$

$\begin{array}{ll}\text { 3. References } & \text { S29 }\end{array}$ 


\section{NMR Spectra}

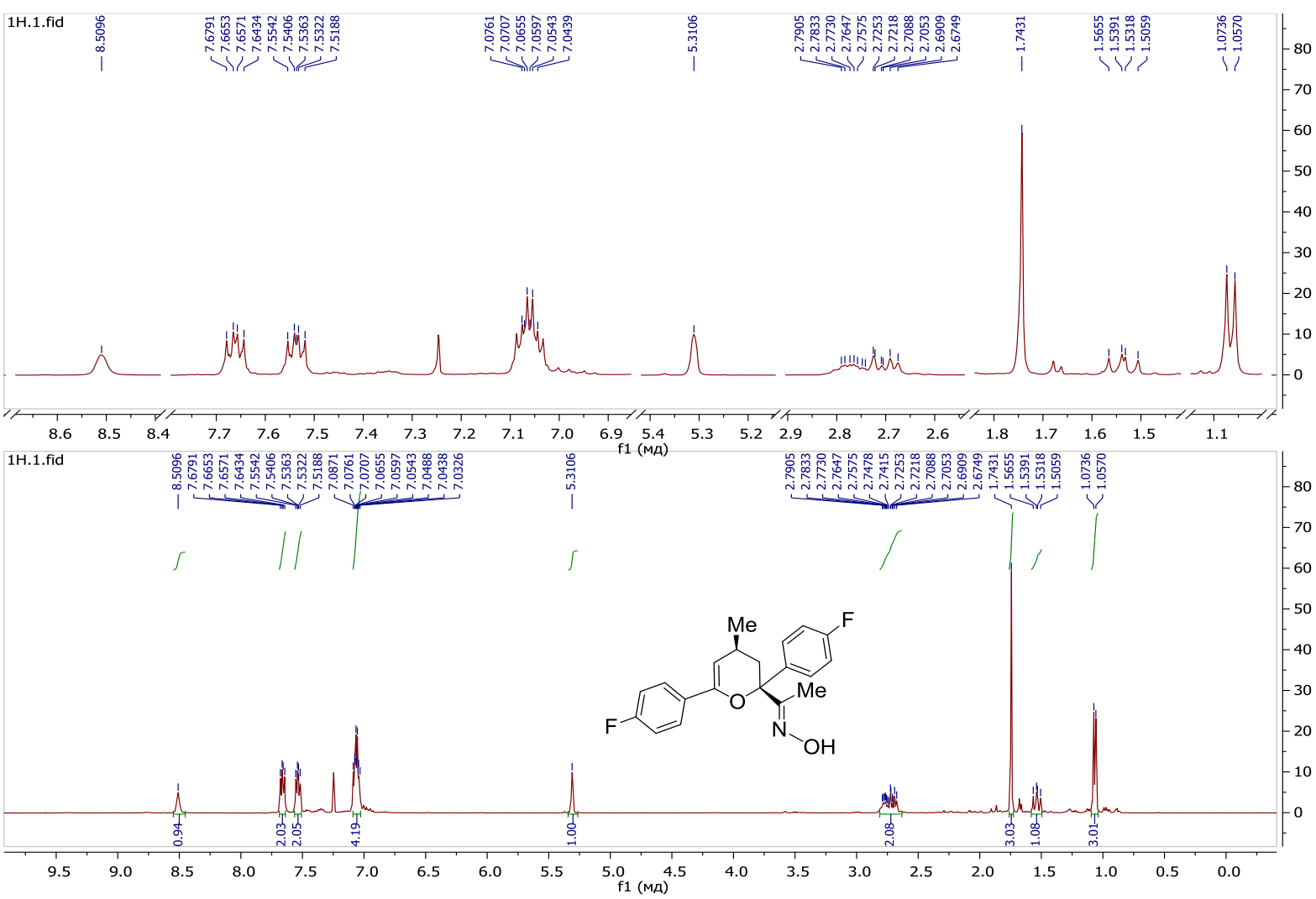

${ }^{1} \mathrm{H}$ NMR Spectrum of $\mathbf{3 c}\left(400 \mathrm{MHz}, \mathrm{CDCl}_{3}\right)$

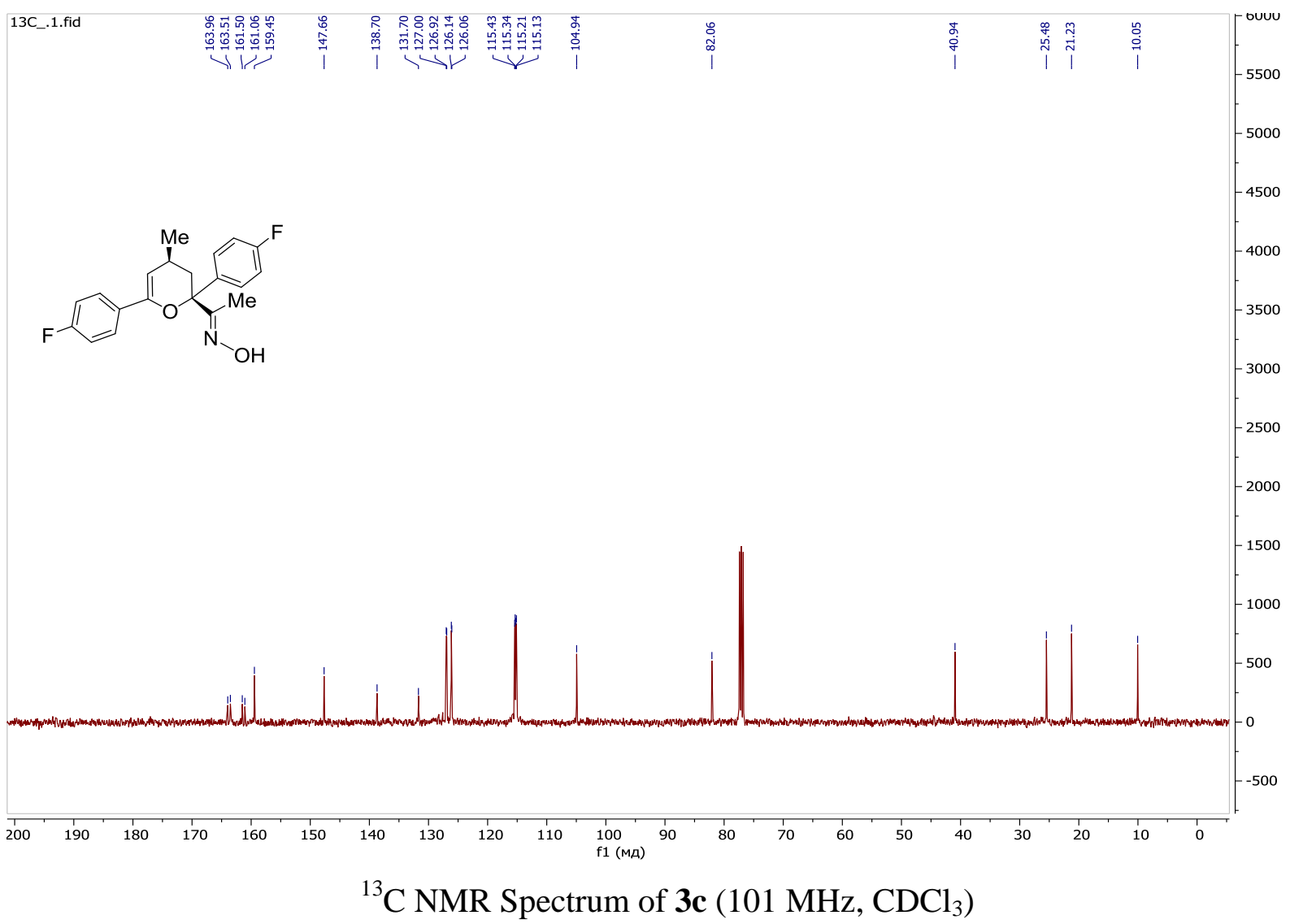




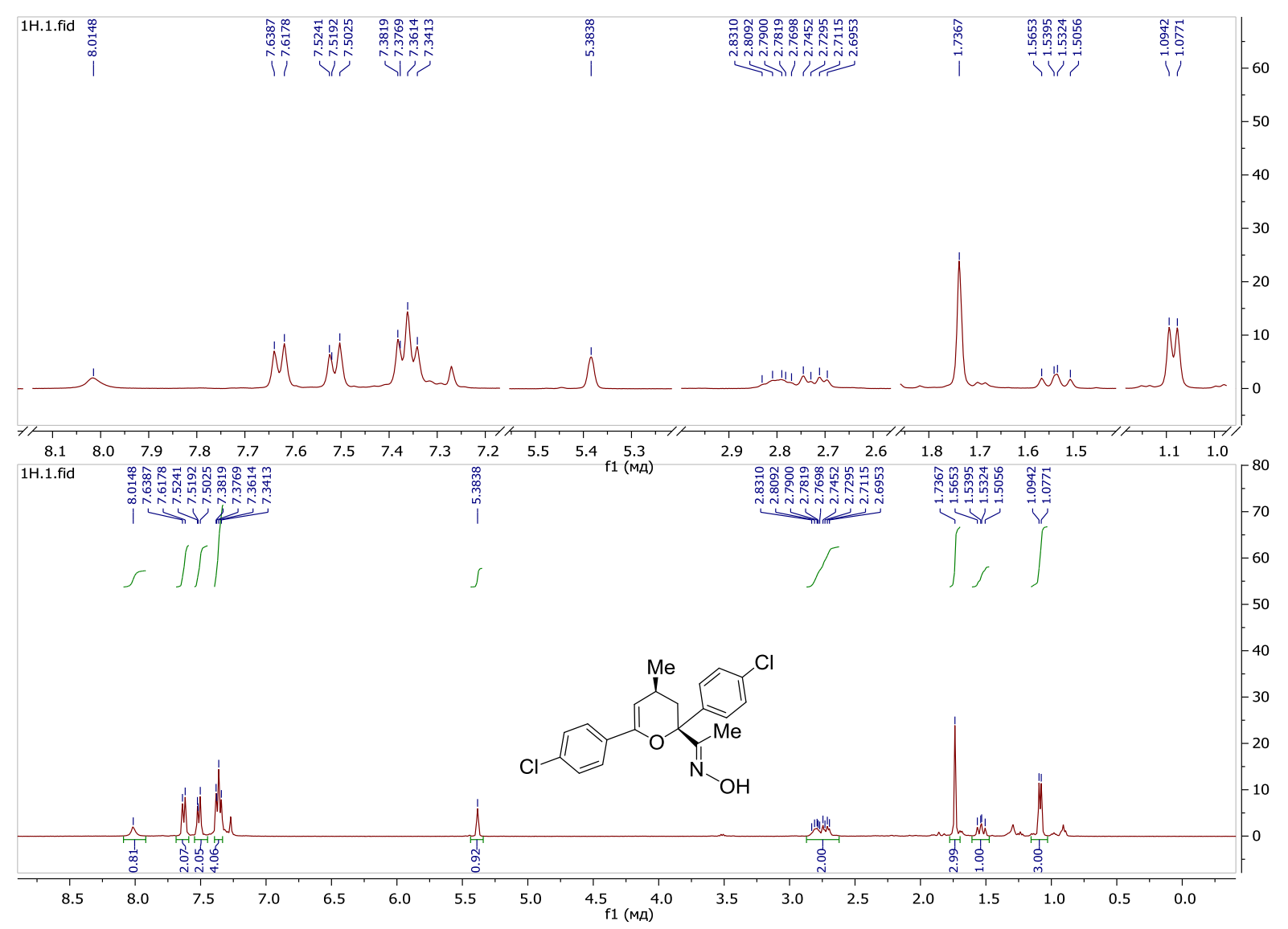

${ }^{1} \mathrm{H}$ NMR Spectrum of $\mathbf{3 d}\left(400 \mathrm{MHz}, \mathrm{CDCl}_{3}\right)$

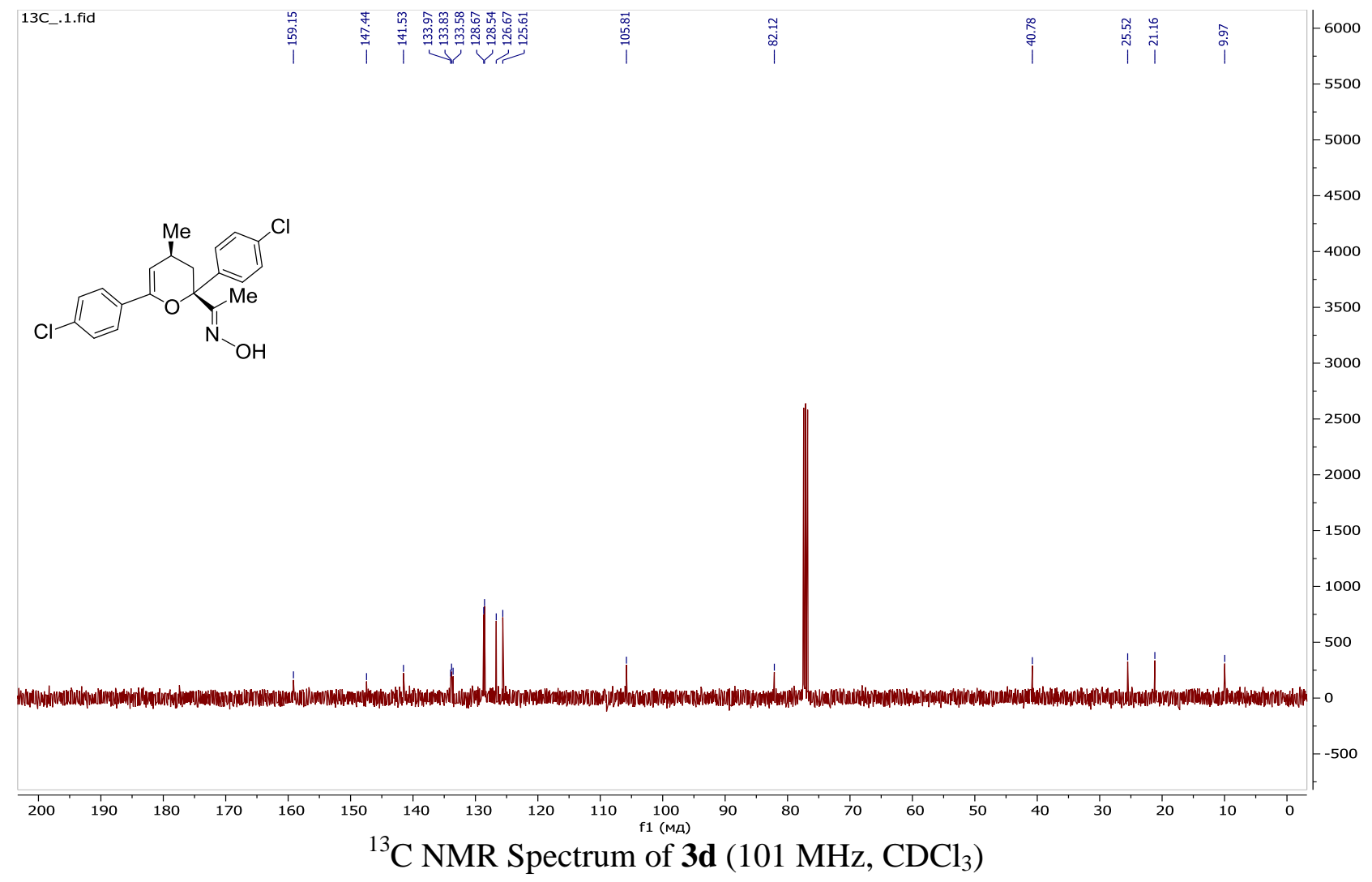




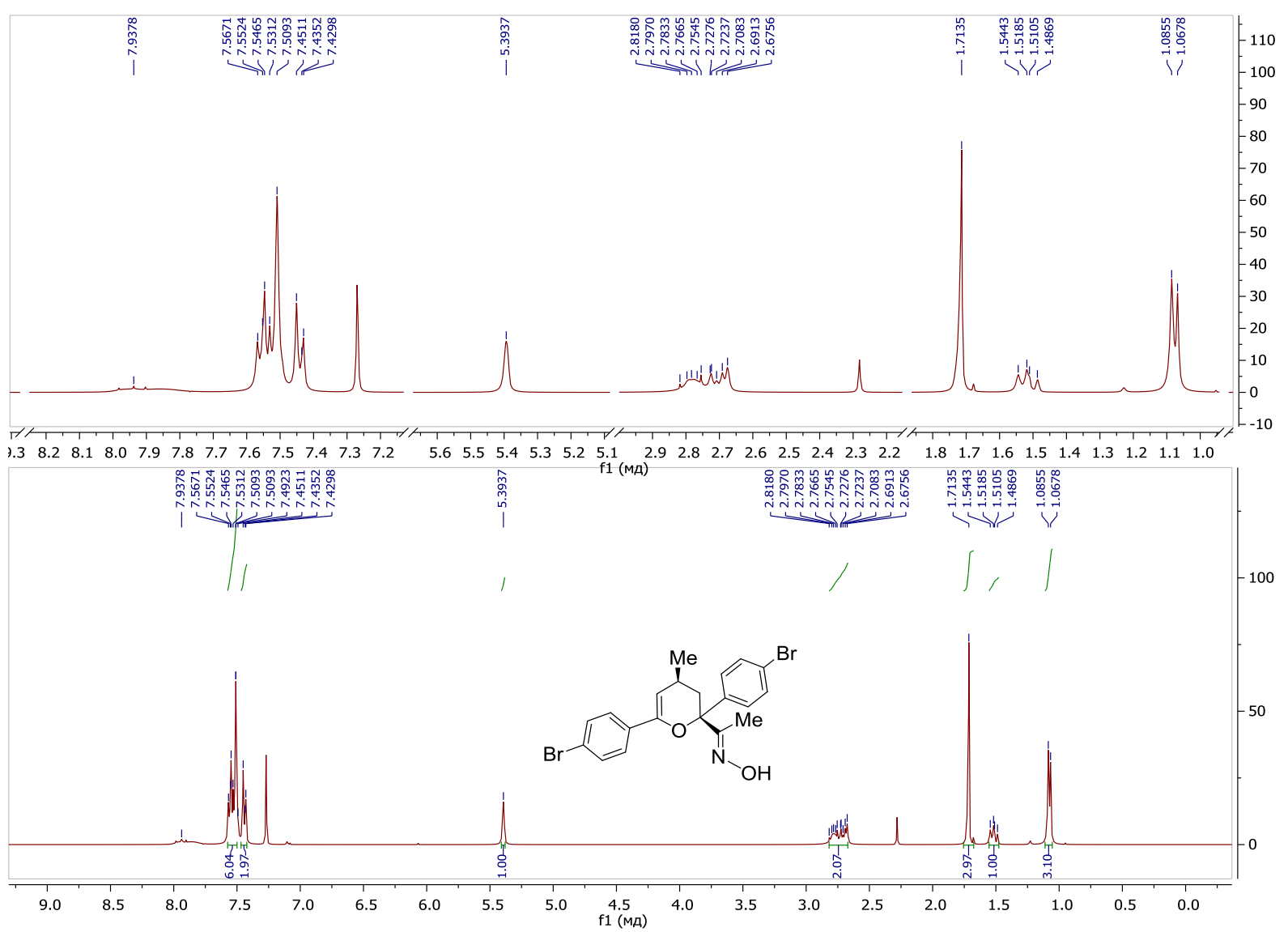

${ }^{1} \mathrm{H}$ NMR Spectrum of $\mathbf{3 e}\left(400 \mathrm{MHz}, \mathrm{CDCl}_{3}\right)$

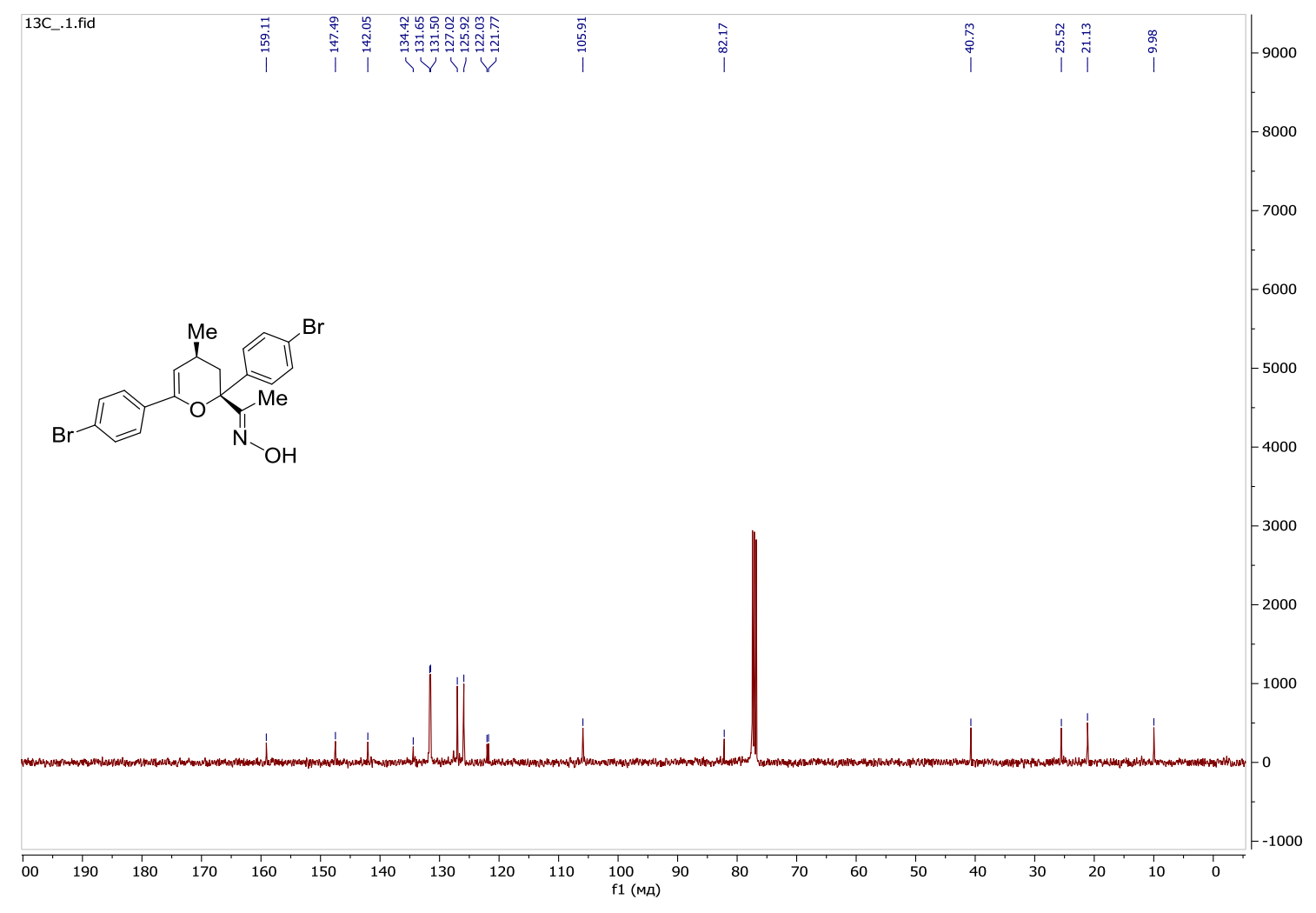

${ }^{13} \mathrm{C}$ NMR Spectrum of $\mathbf{3 e}\left(101 \mathrm{MHz}, \mathrm{CDCl}_{3}\right)$ 


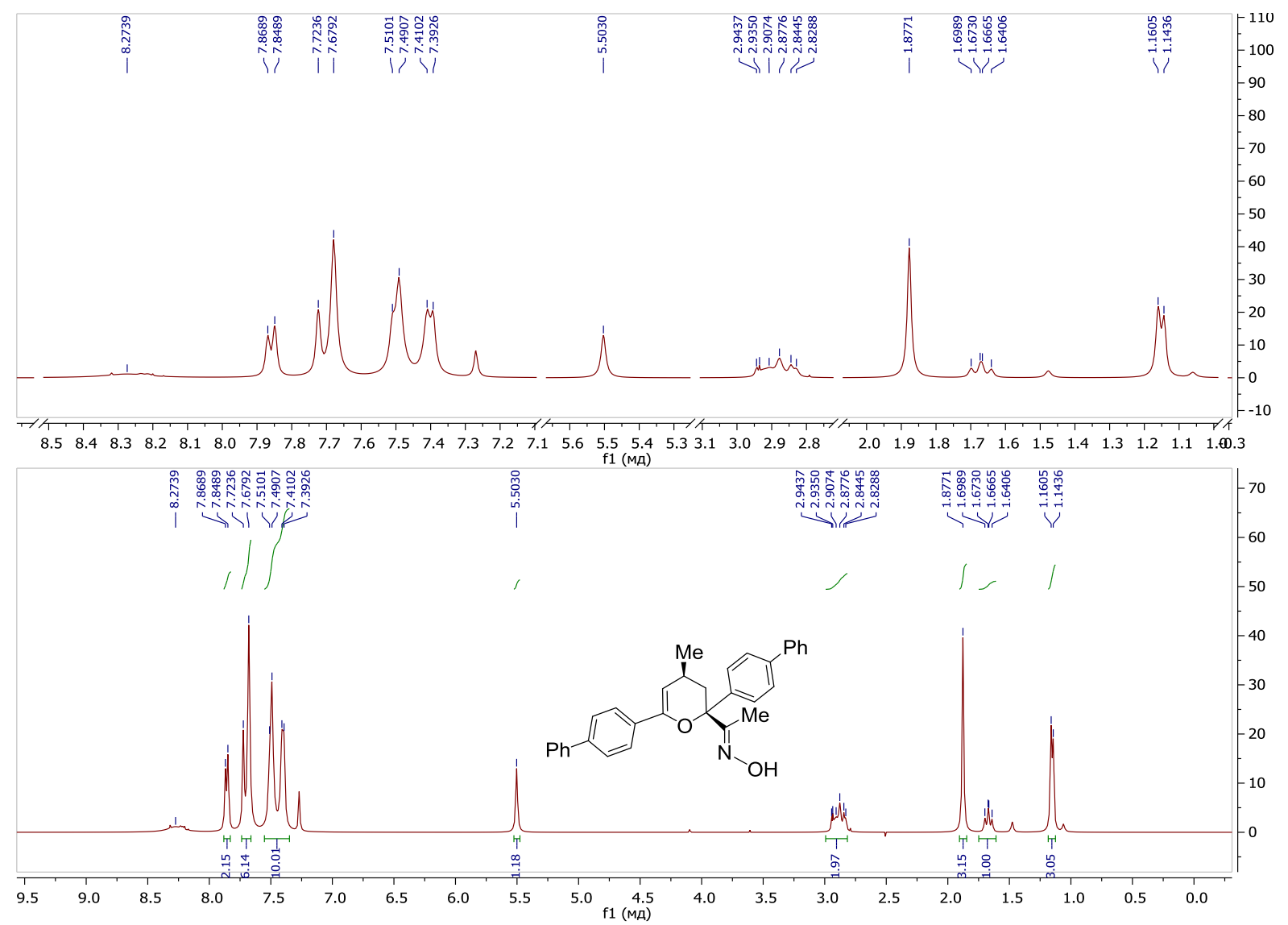

${ }^{1} \mathrm{H}$ NMR Spectrum of $\mathbf{3 g}\left(400 \mathrm{MHz}, \mathrm{CDCl}_{3}\right)$

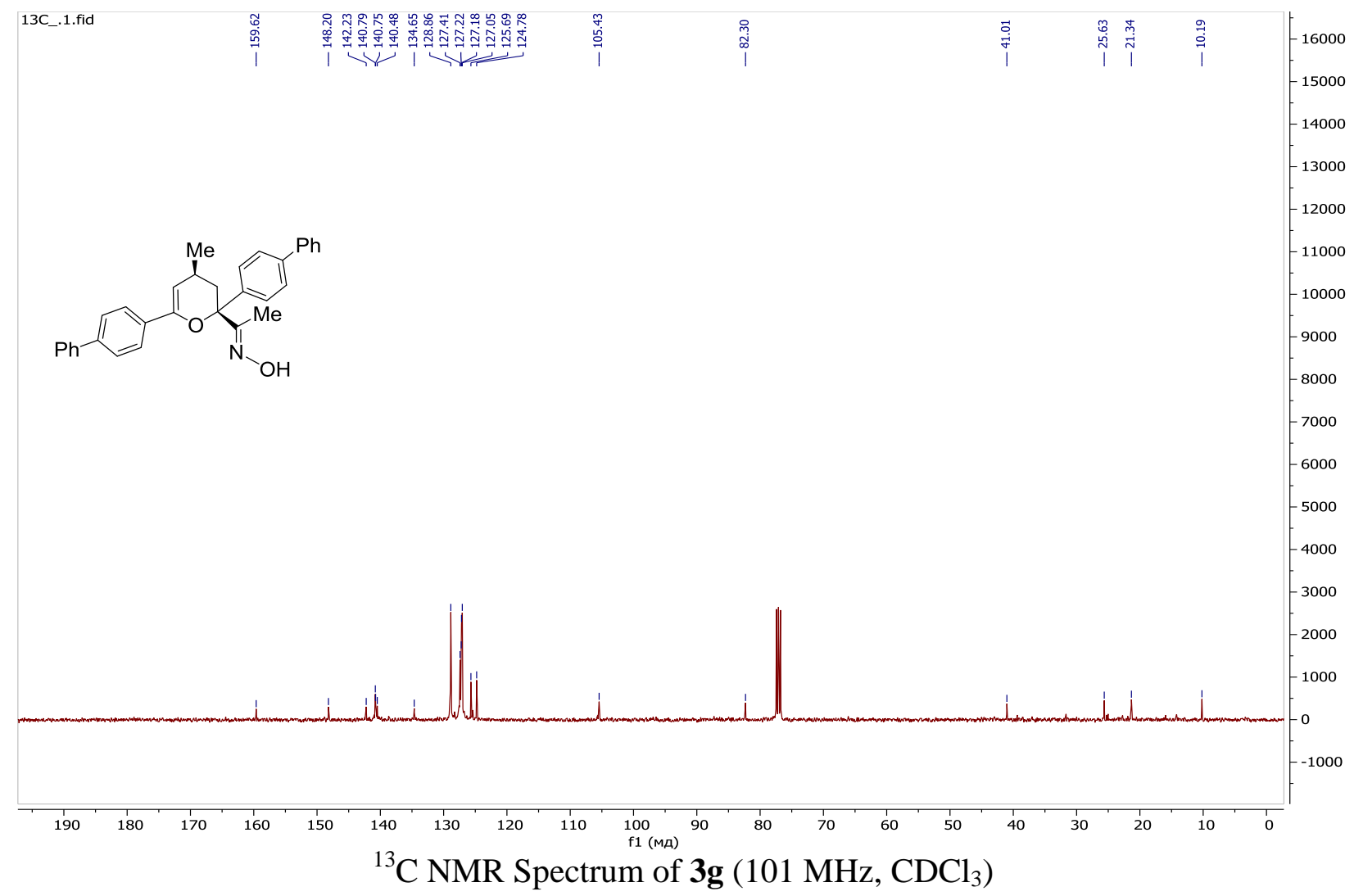




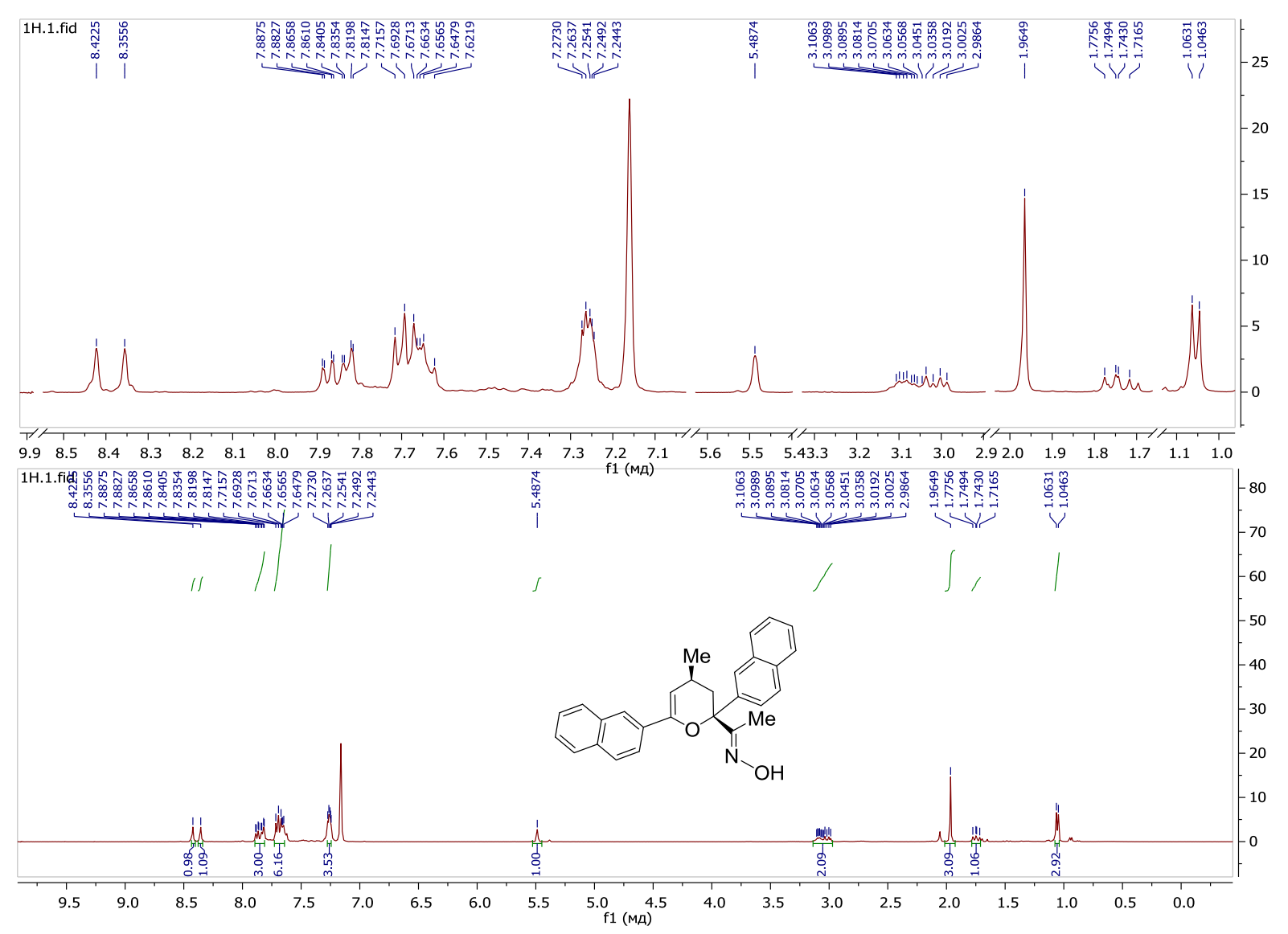

${ }^{1} \mathrm{H}$ NMR Spectrum of $\mathbf{3 h}\left(400 \mathrm{MHz}, \mathrm{C}_{6} \mathrm{D}_{6}\right)$

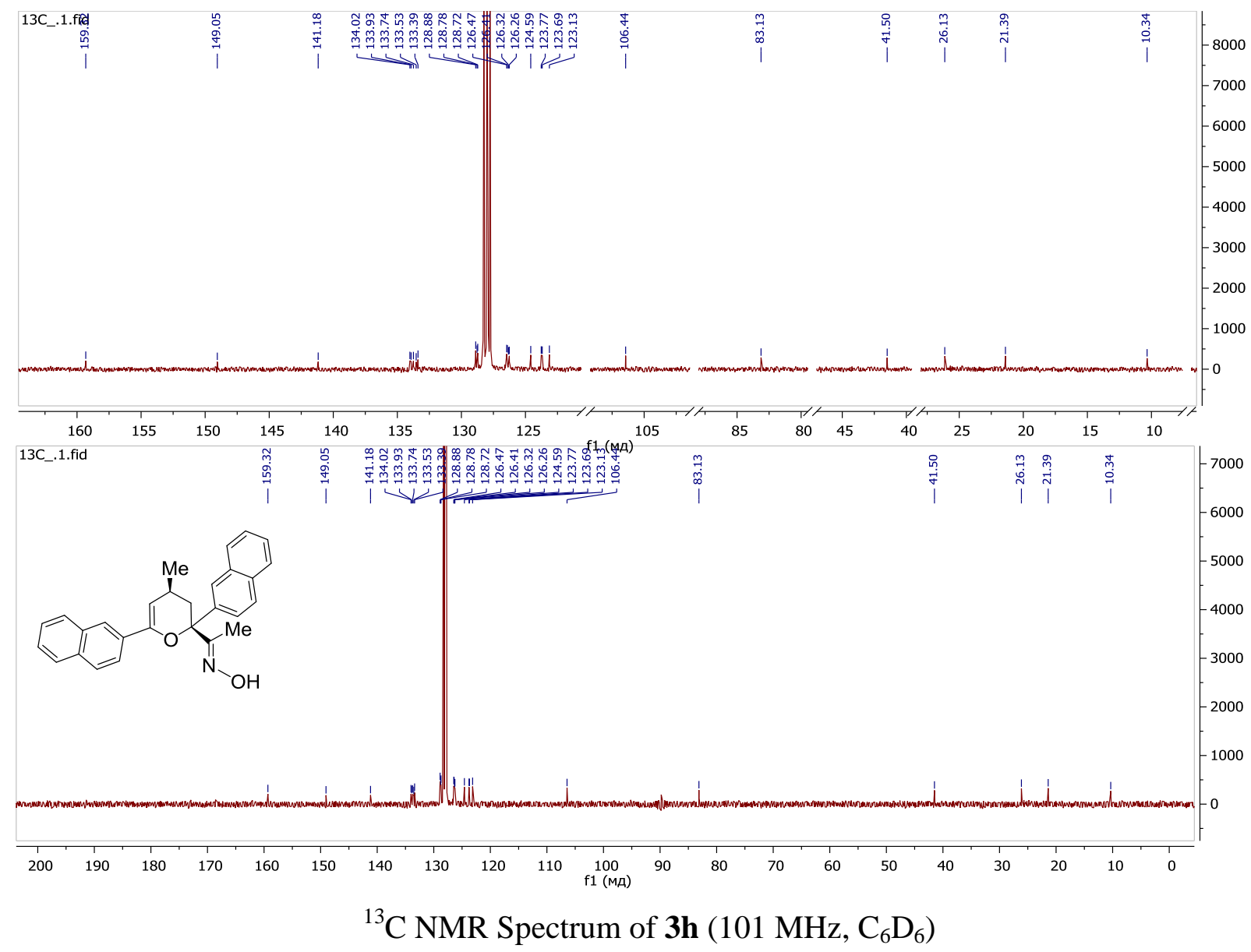



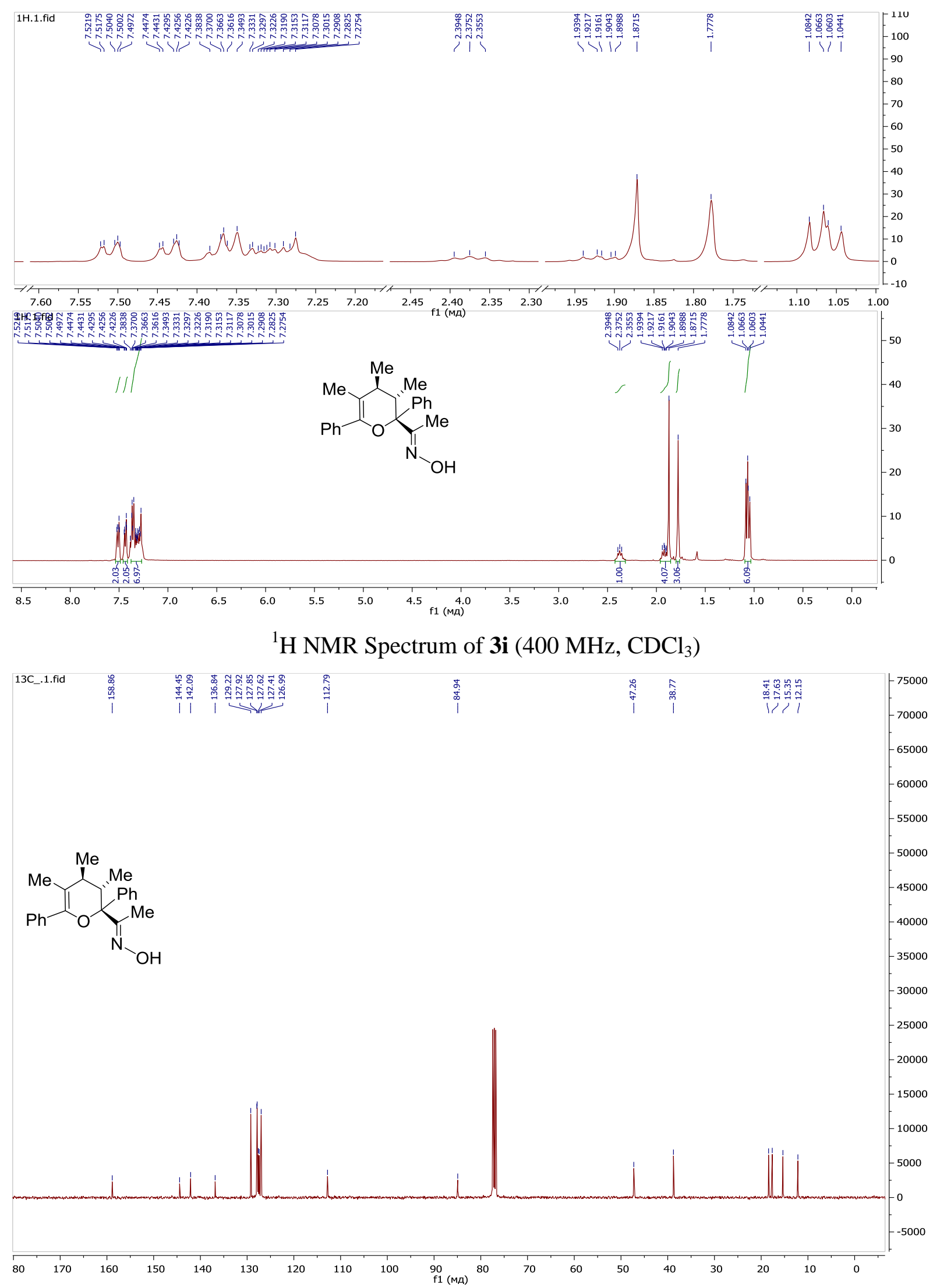

${ }^{13} \mathrm{C}$ NMR Spectrum of $\mathbf{3 i}\left(101 \mathrm{MHz}, \mathrm{CDCl}_{3}\right)$ 


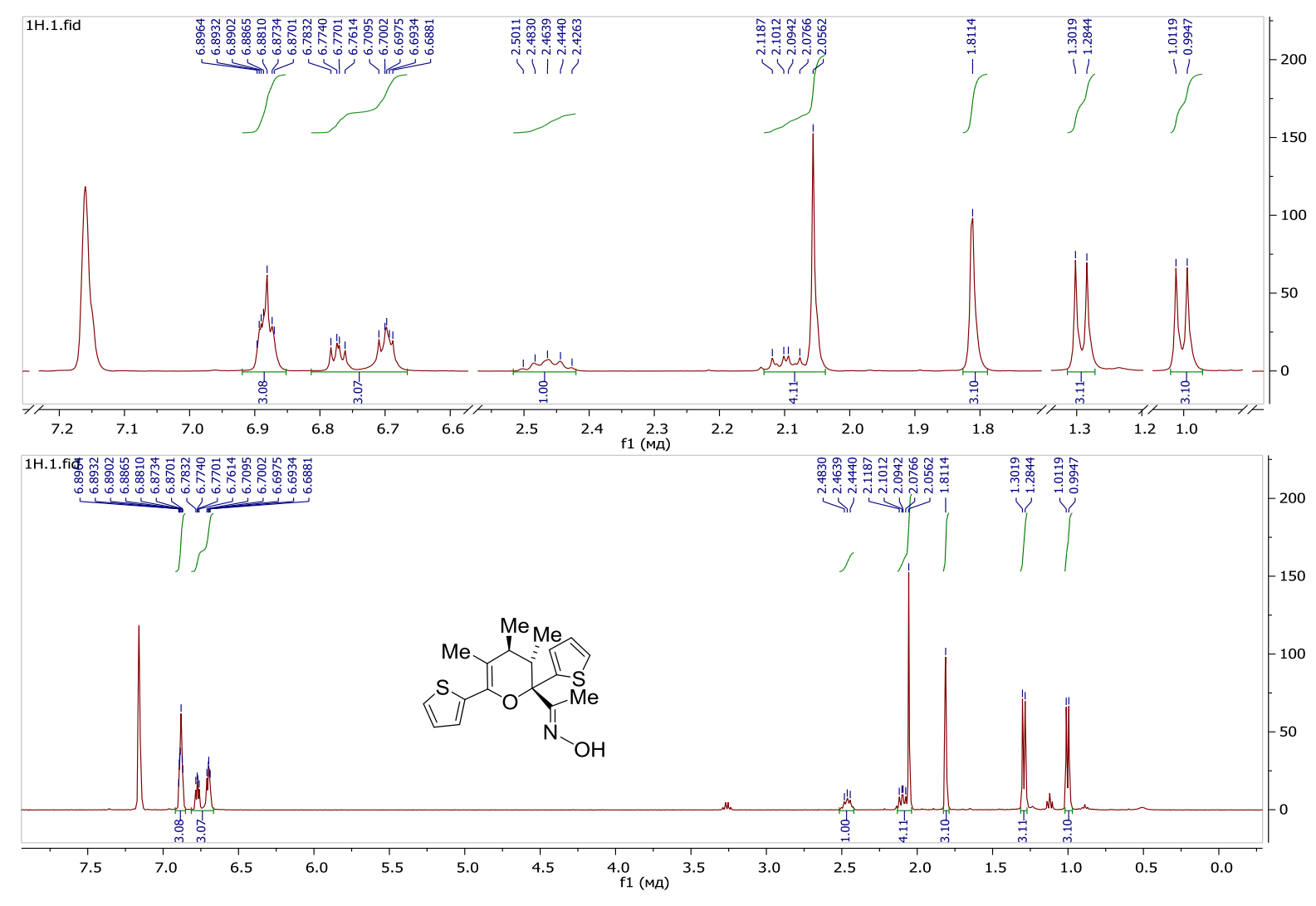

${ }^{1}$ H NMR Spectrum of $\mathbf{3 k}\left(400 \mathrm{MHz}, \mathrm{C}_{6} \mathrm{D}_{6}\right)$

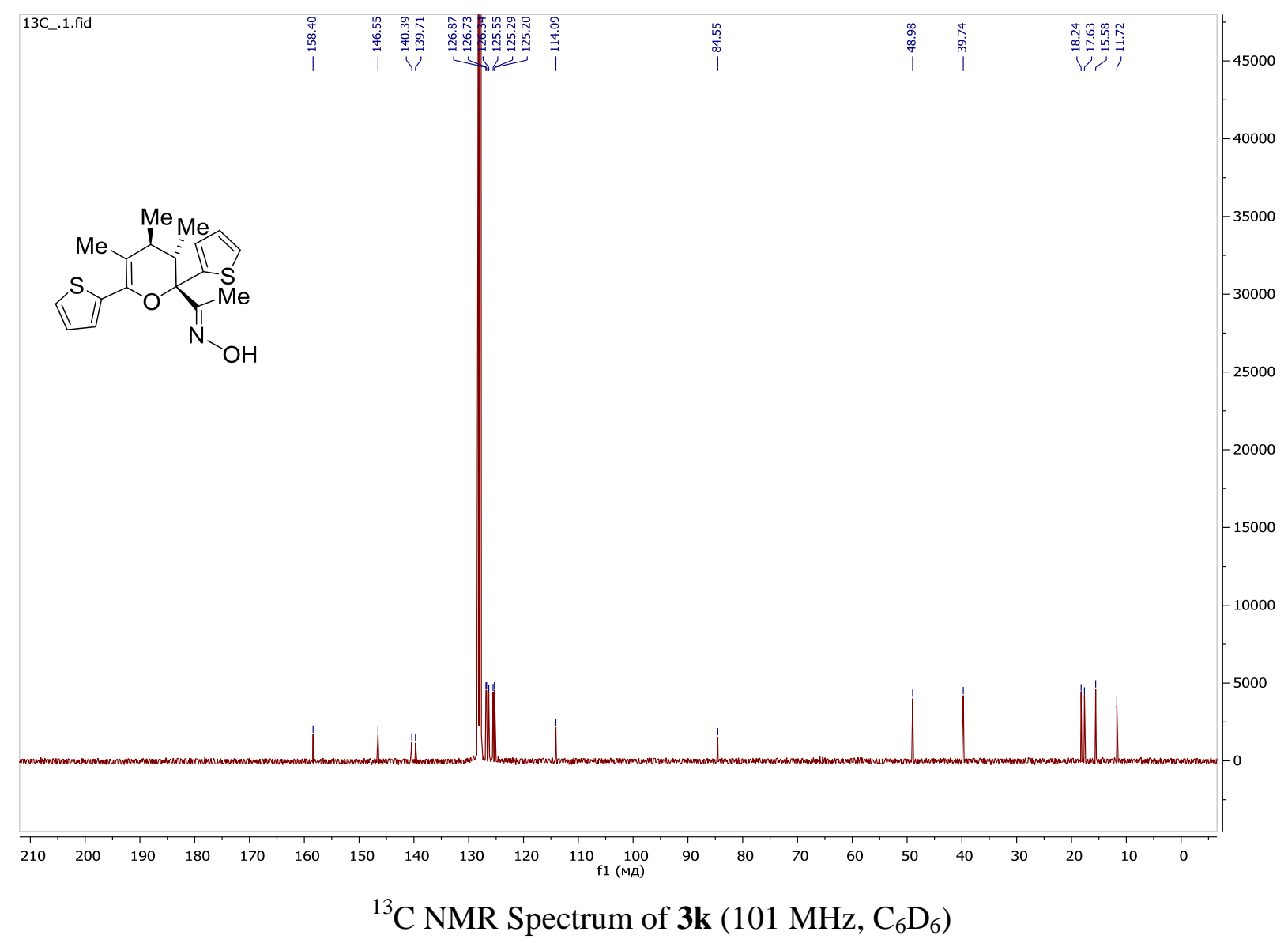



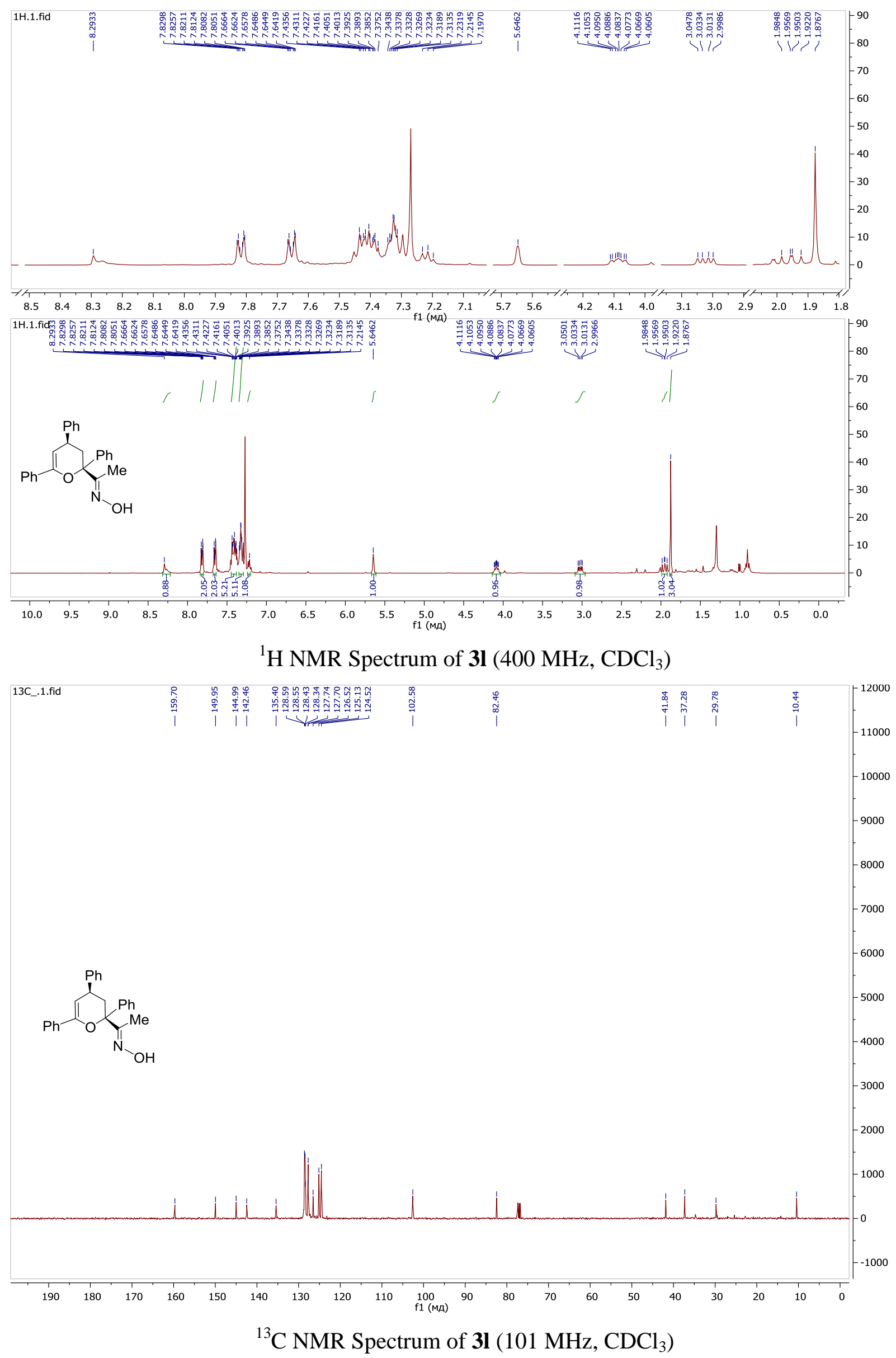


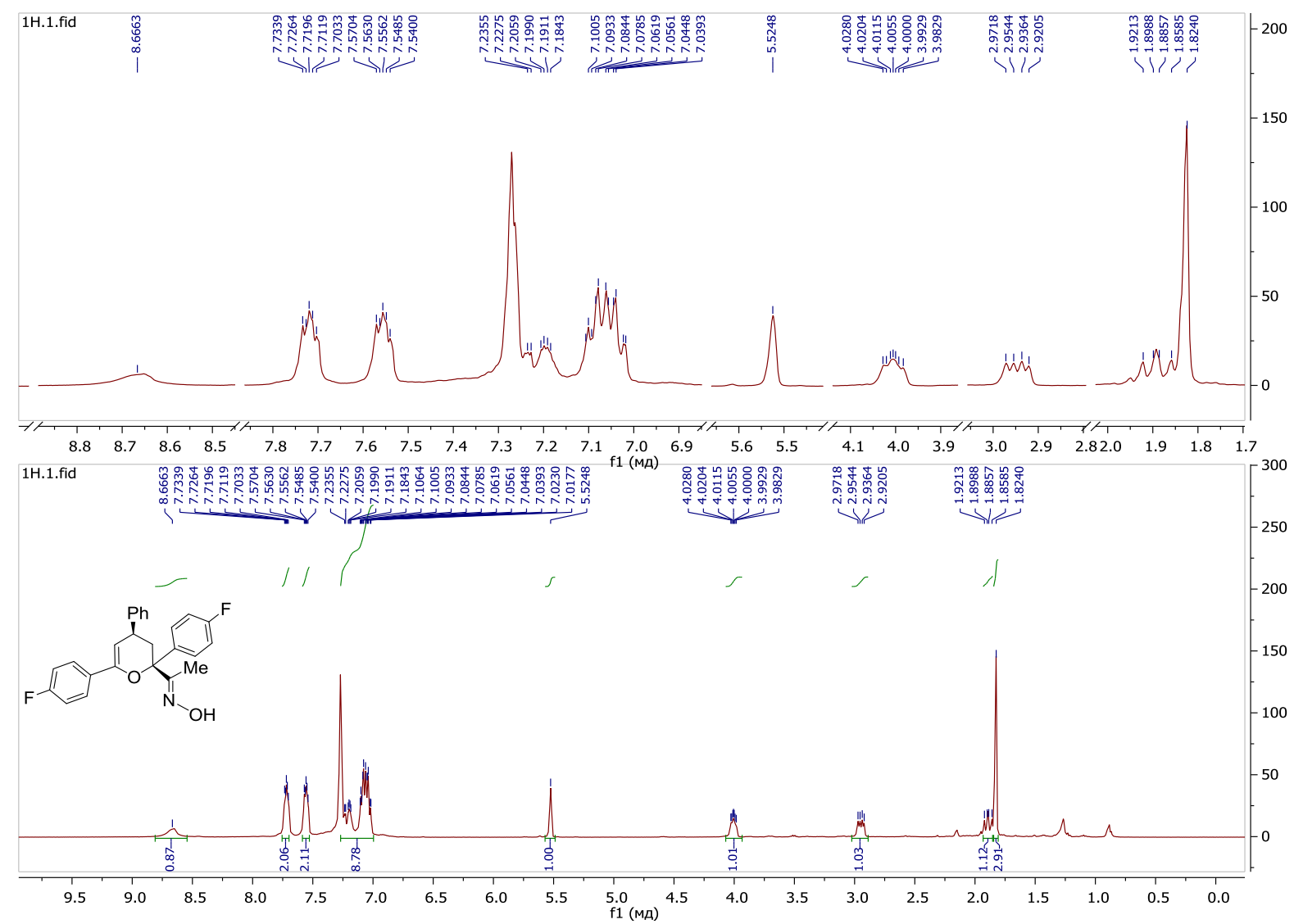

${ }^{1} \mathrm{H}$ NMR Spectrum of $\mathbf{3 m}\left(400 \mathrm{MHz}, \mathrm{CDCl}_{3}\right)$

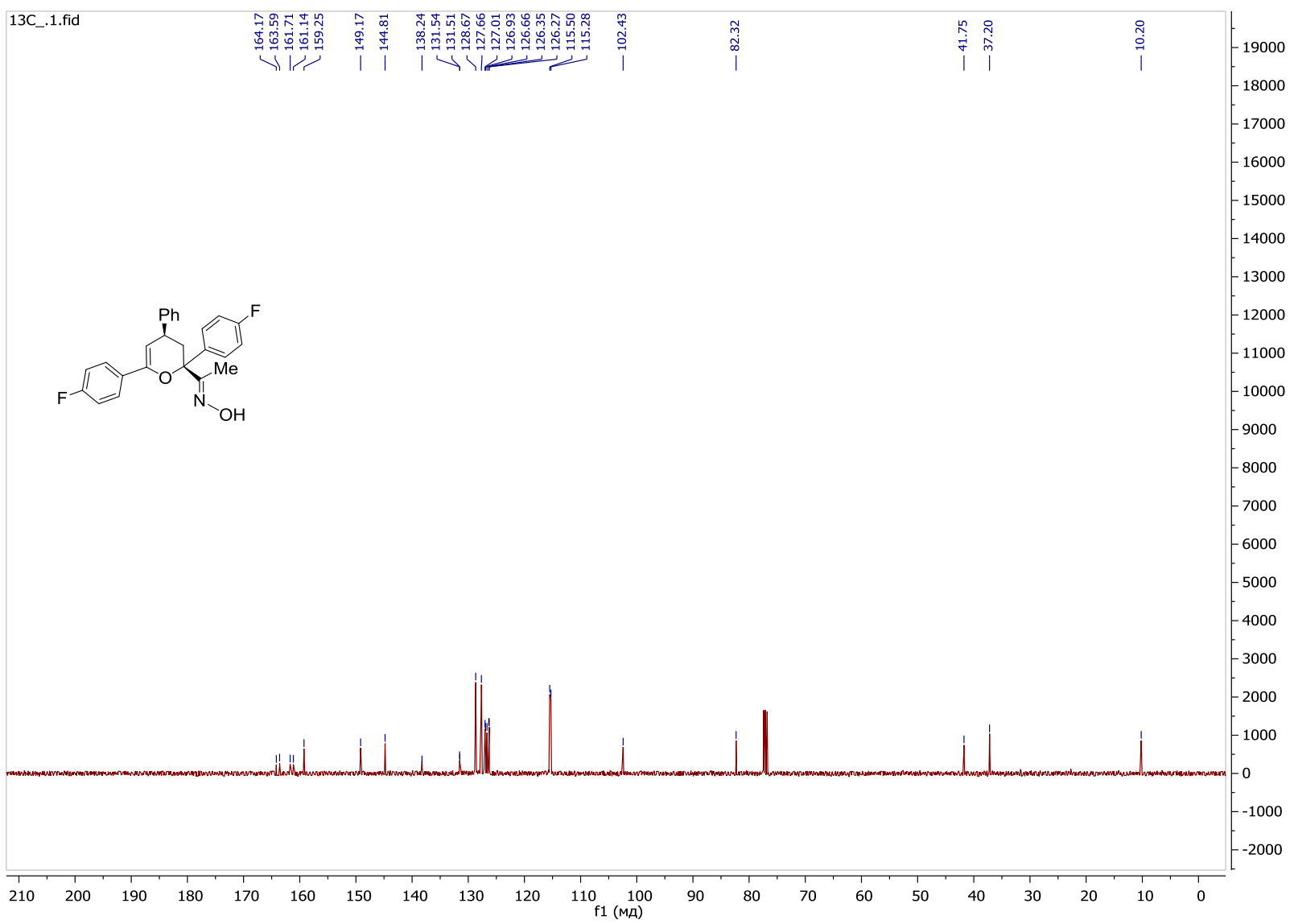

${ }^{13} \mathrm{C}$ NMR Spectrum of $\mathbf{3 m}\left(101 \mathrm{MHz}, \mathrm{CDCl}_{3}\right)$ 


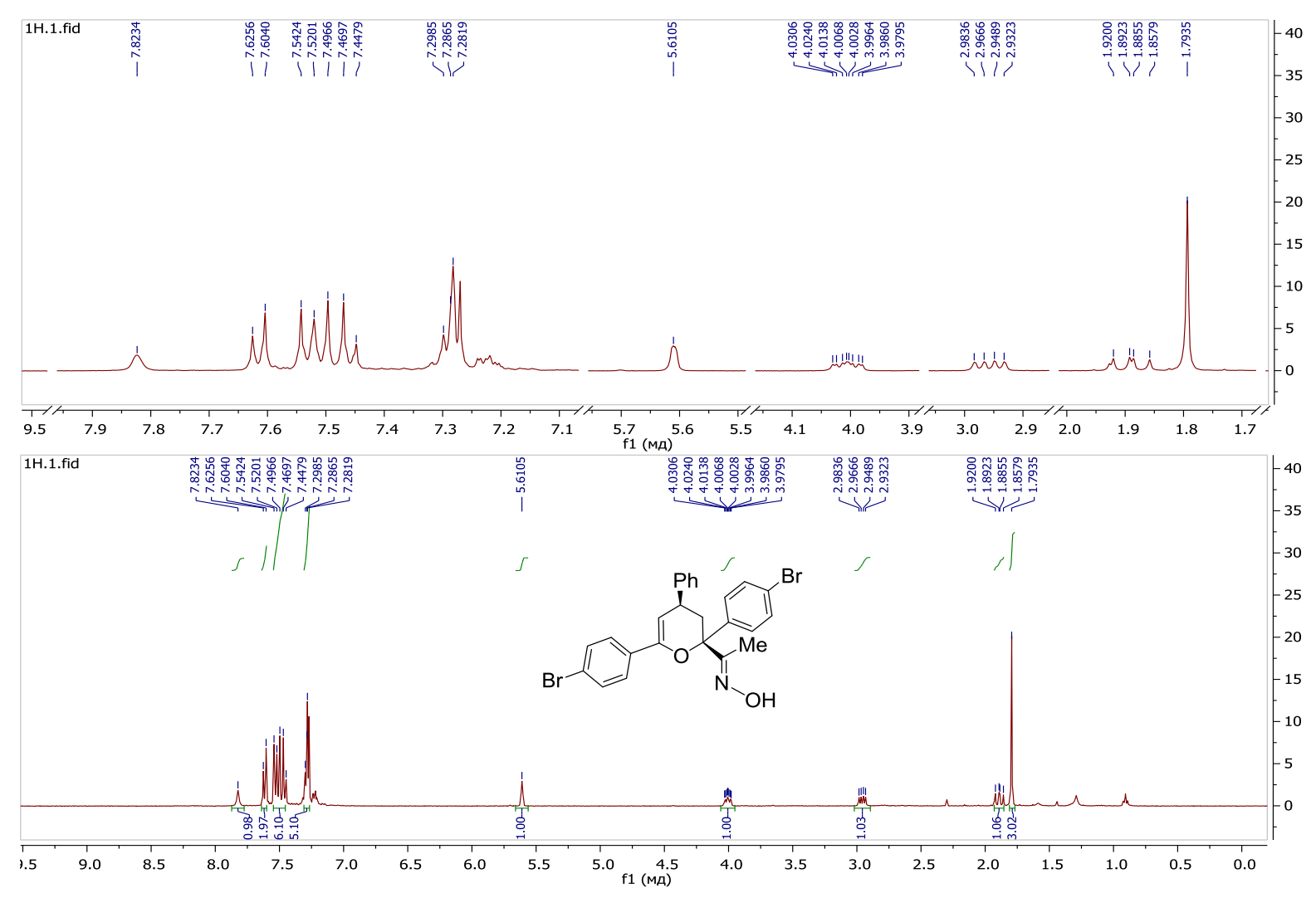

${ }^{1} \mathrm{H}$ NMR Spectrum of 3n (400 MHz, $\mathrm{CDCl}_{3}$ )

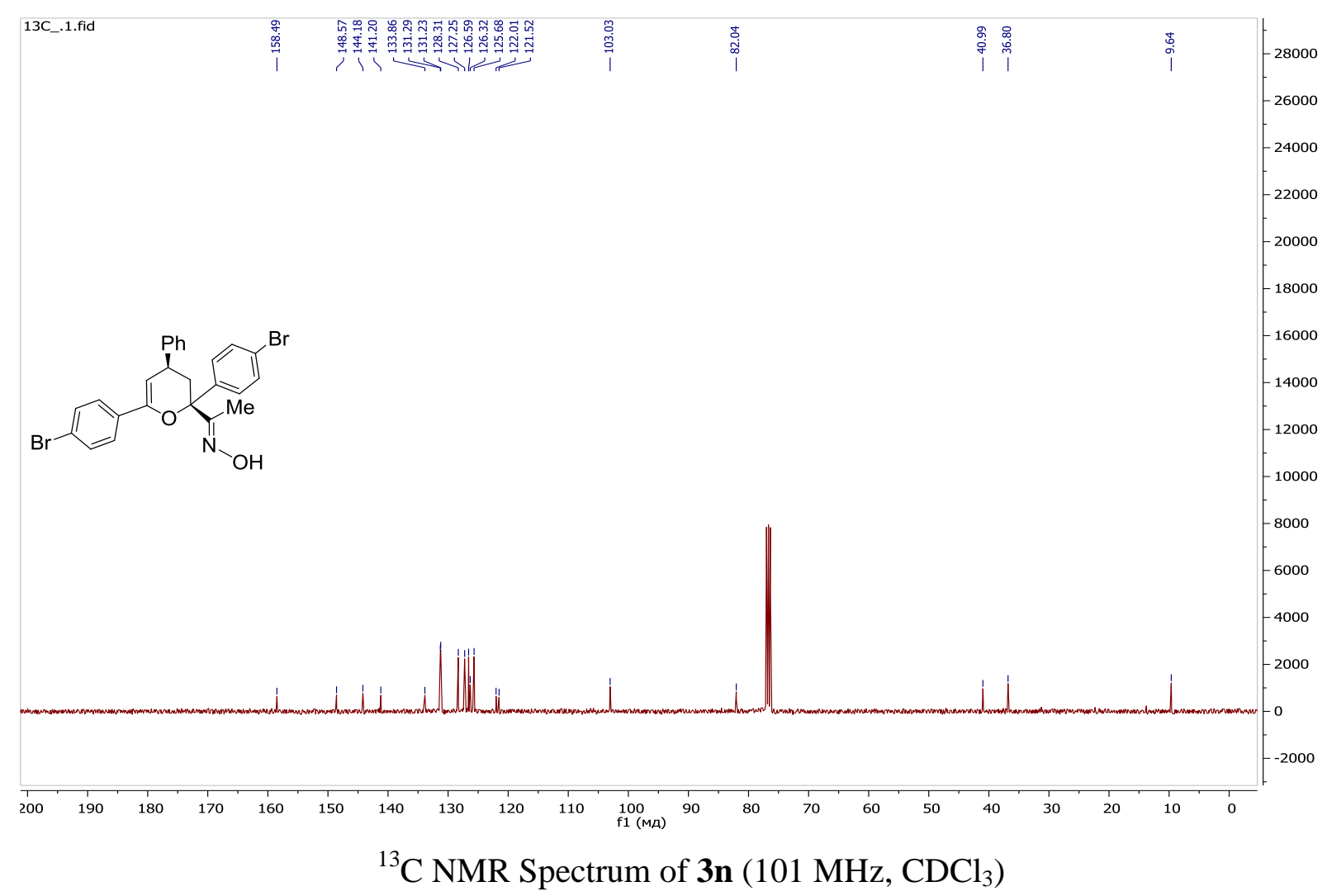




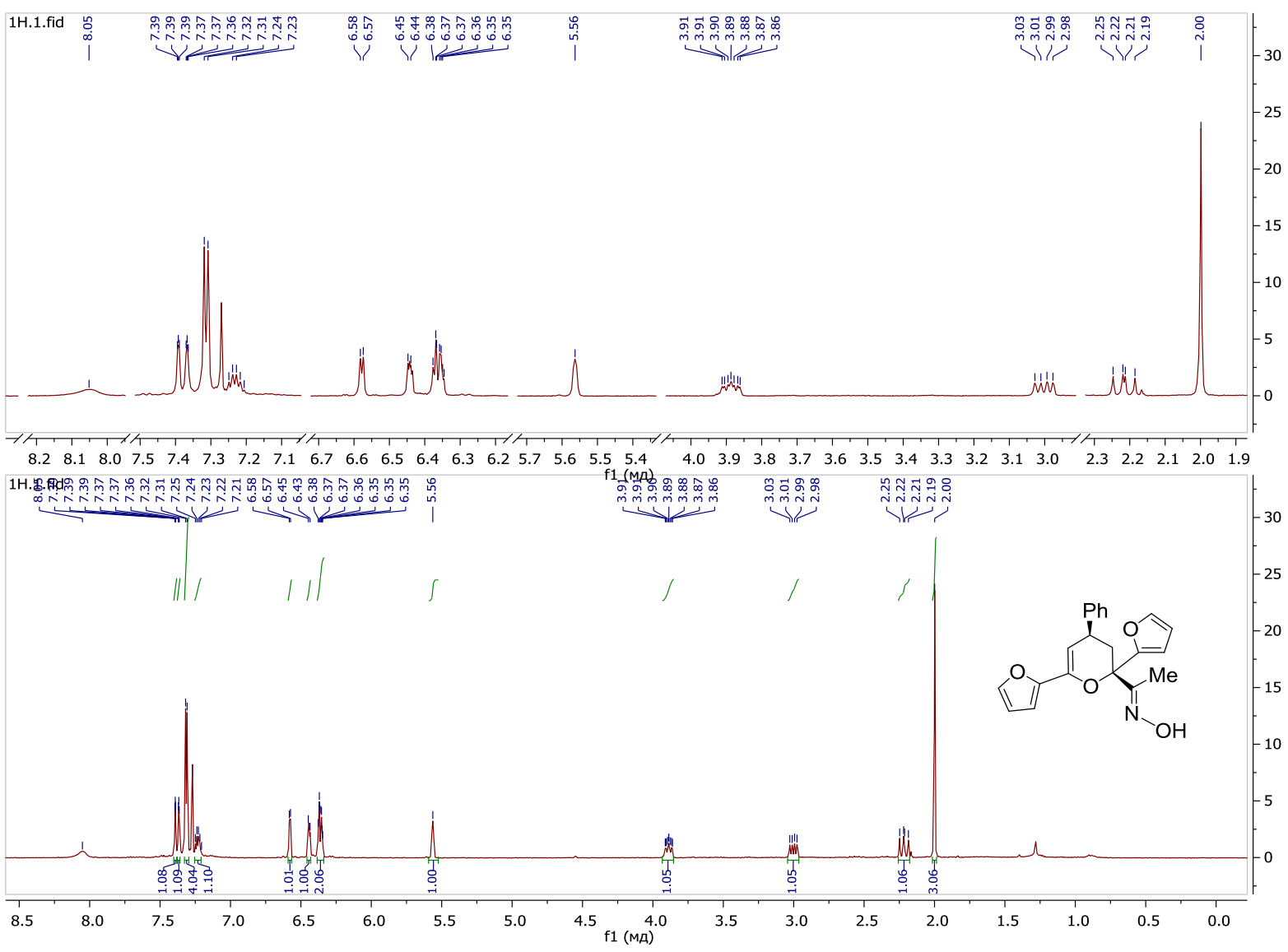

${ }^{1} \mathrm{H}$ NMR Spectrum of $3 \mathbf{3}\left(400 \mathrm{MHz}, \mathrm{CDCl}_{3}\right)$

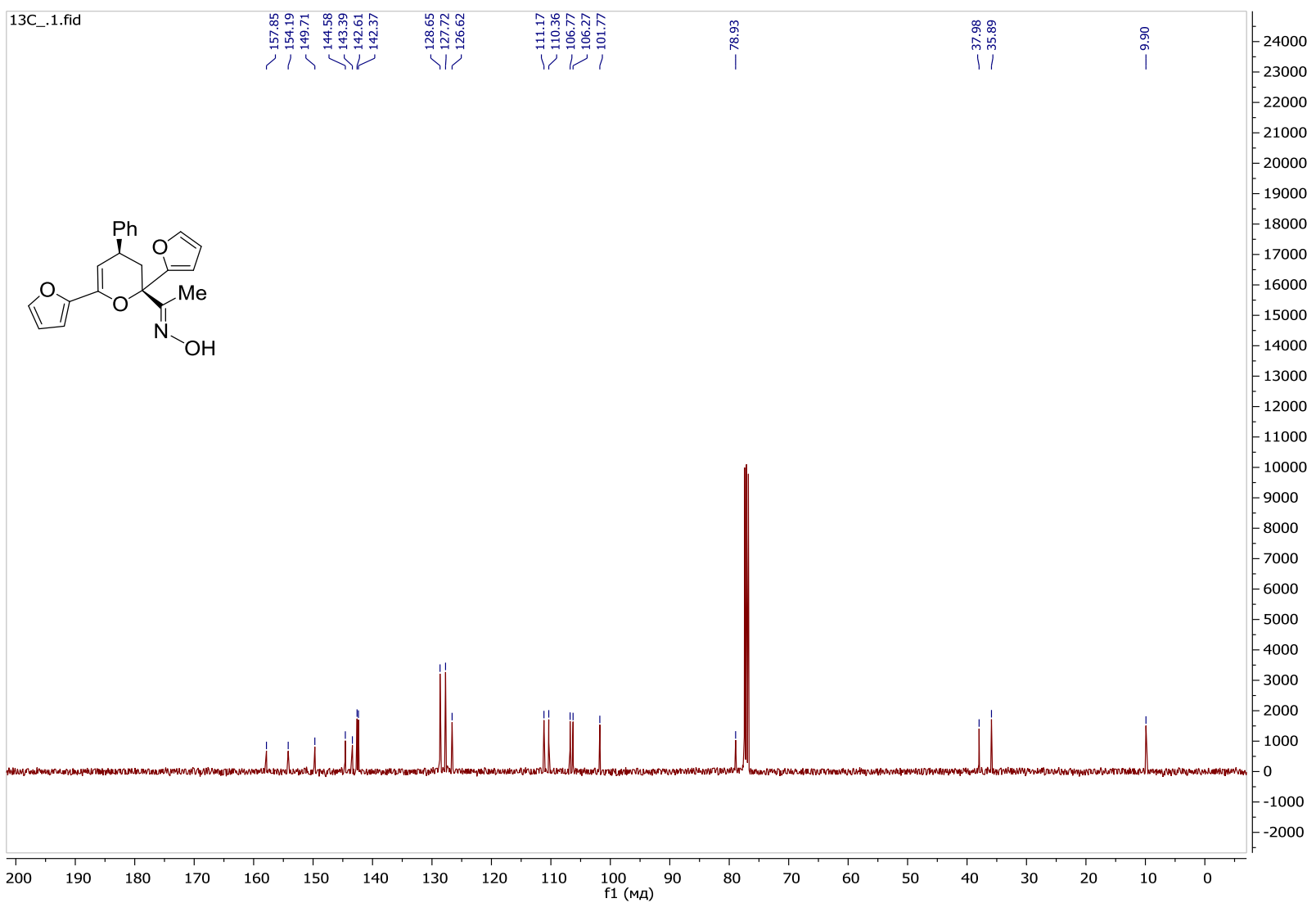

${ }^{13} \mathrm{C}$ NMR Spectrum of $\mathbf{3 o}\left(101 \mathrm{MHz}, \mathrm{CDCl}_{3}\right)$ 


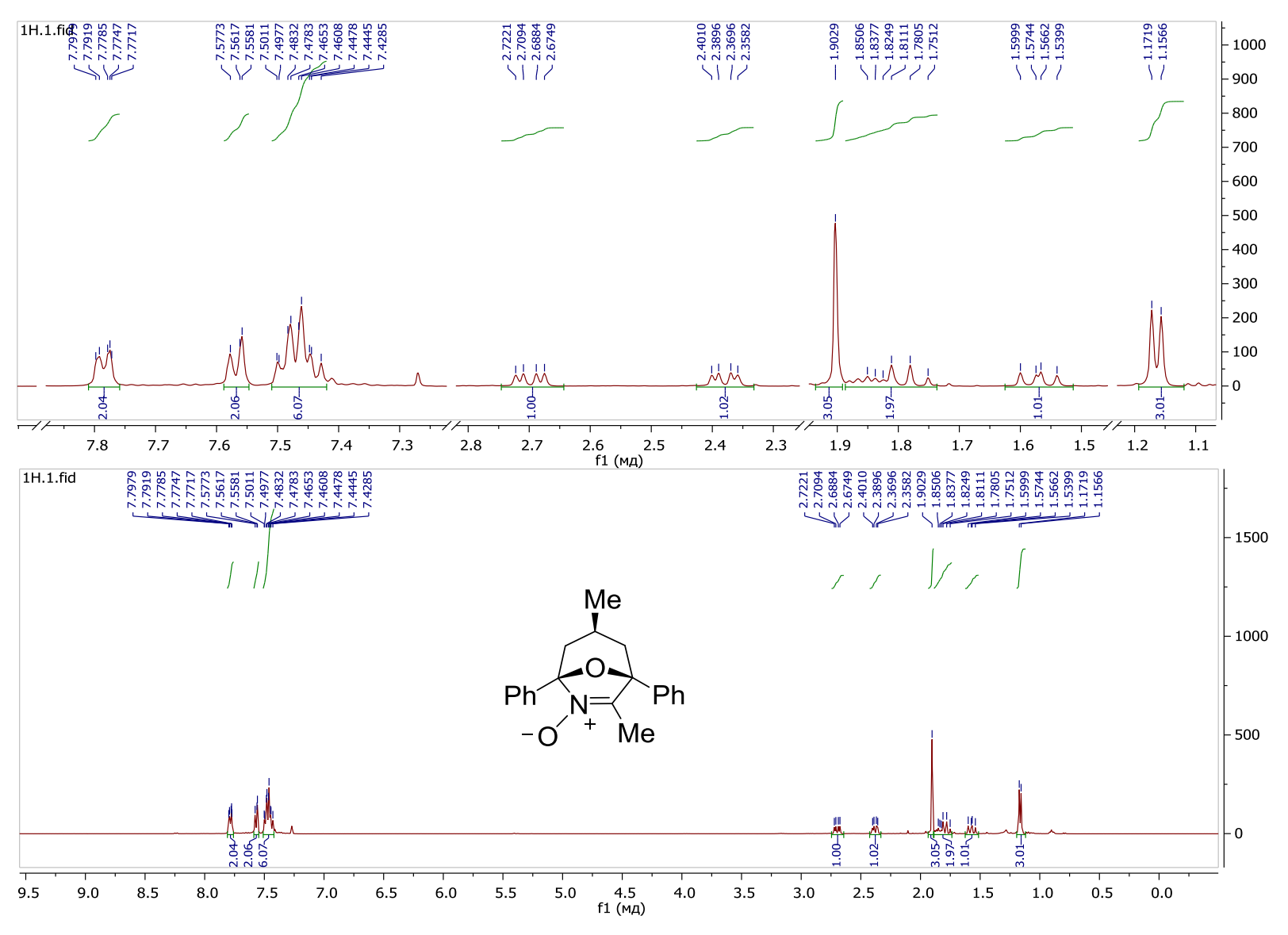

${ }^{1} \mathrm{H}$ NMR Spectrum of $\mathbf{4 a}\left(400 \mathrm{MHz}, \mathrm{CDCl}_{3}\right)$

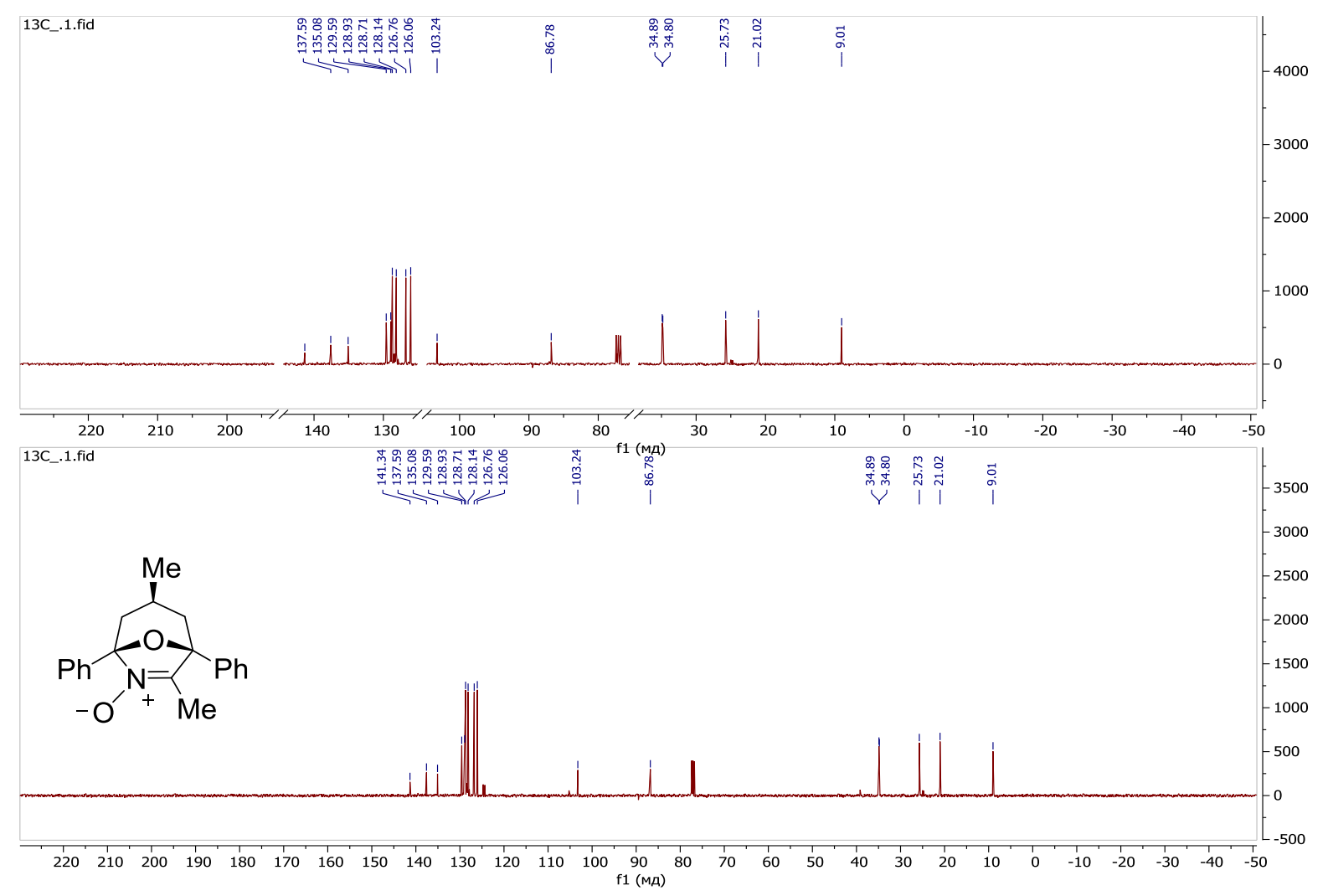

${ }^{13} \mathrm{C}$ NMR Spectrum of $\mathbf{4 a}\left(101 \mathrm{MHz}, \mathrm{CDCl}_{3}\right)$ 


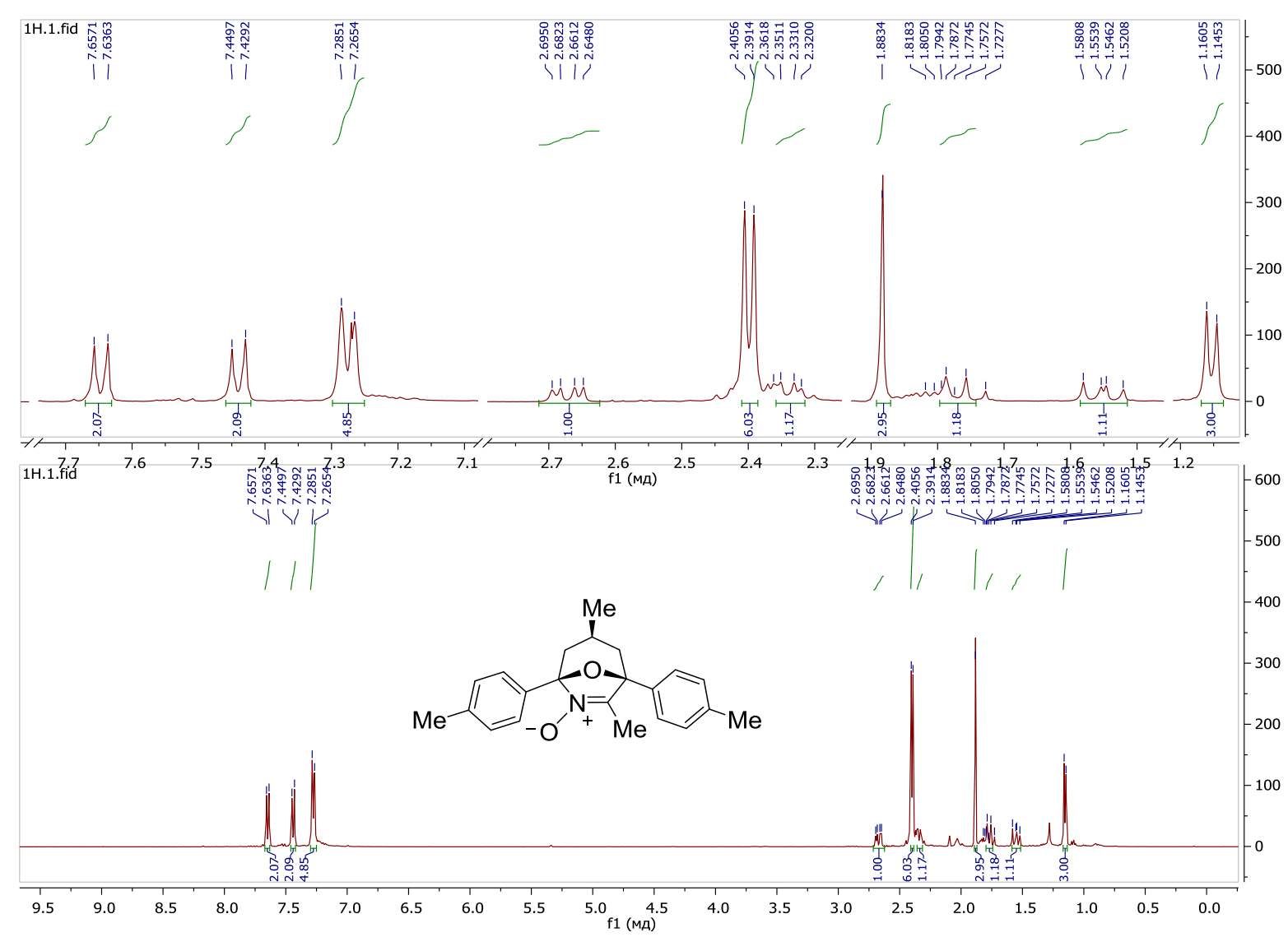

${ }^{1} \mathrm{H}$ NMR Spectrum of $\mathbf{4 b}\left(400 \mathrm{MHz}, \mathrm{CDCl}_{3}\right)$

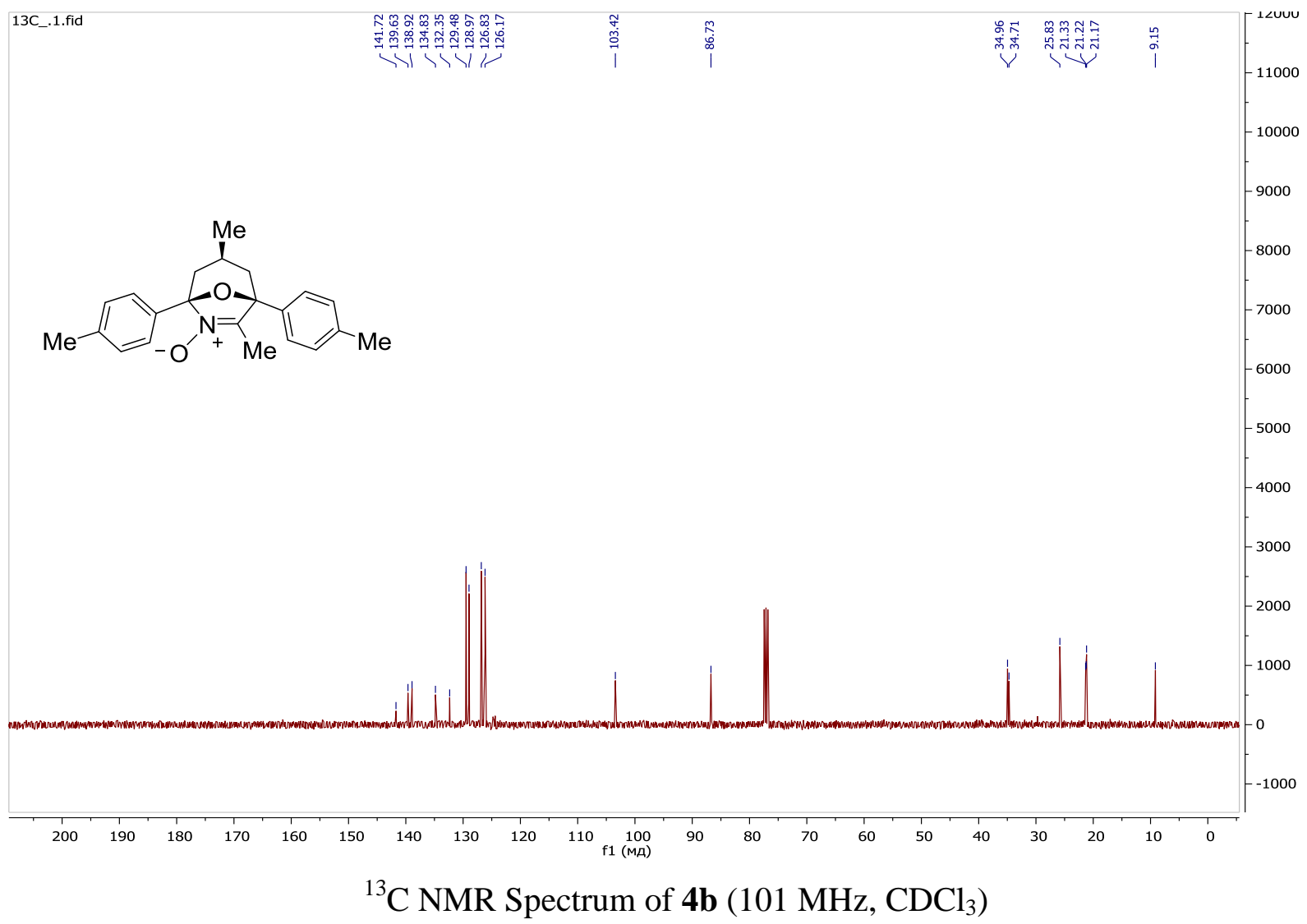




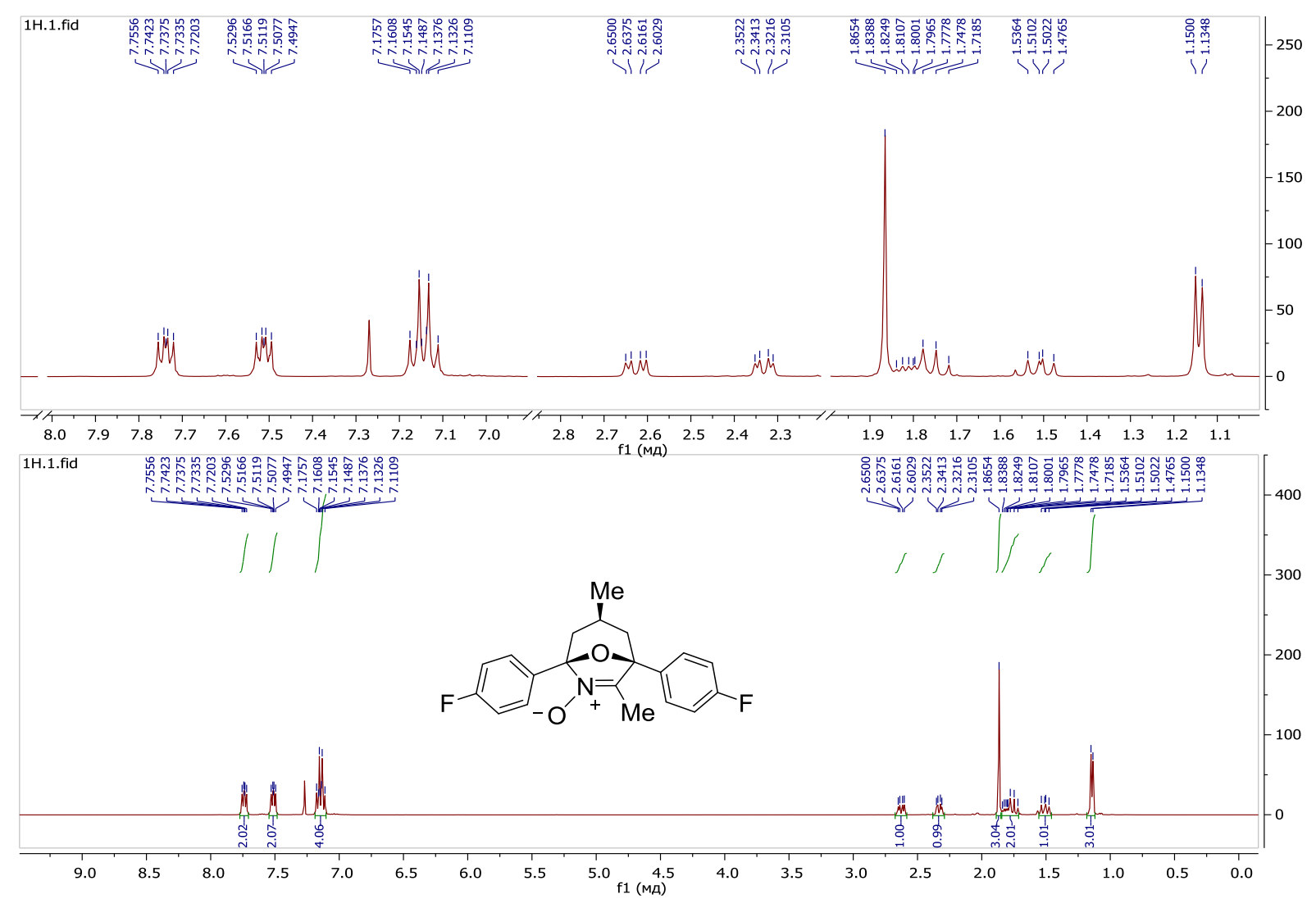

${ }^{1} \mathrm{H}$ NMR Spectrum of $\mathbf{4 c}\left(400 \mathrm{MHz}, \mathrm{CDCl}_{3}\right)$

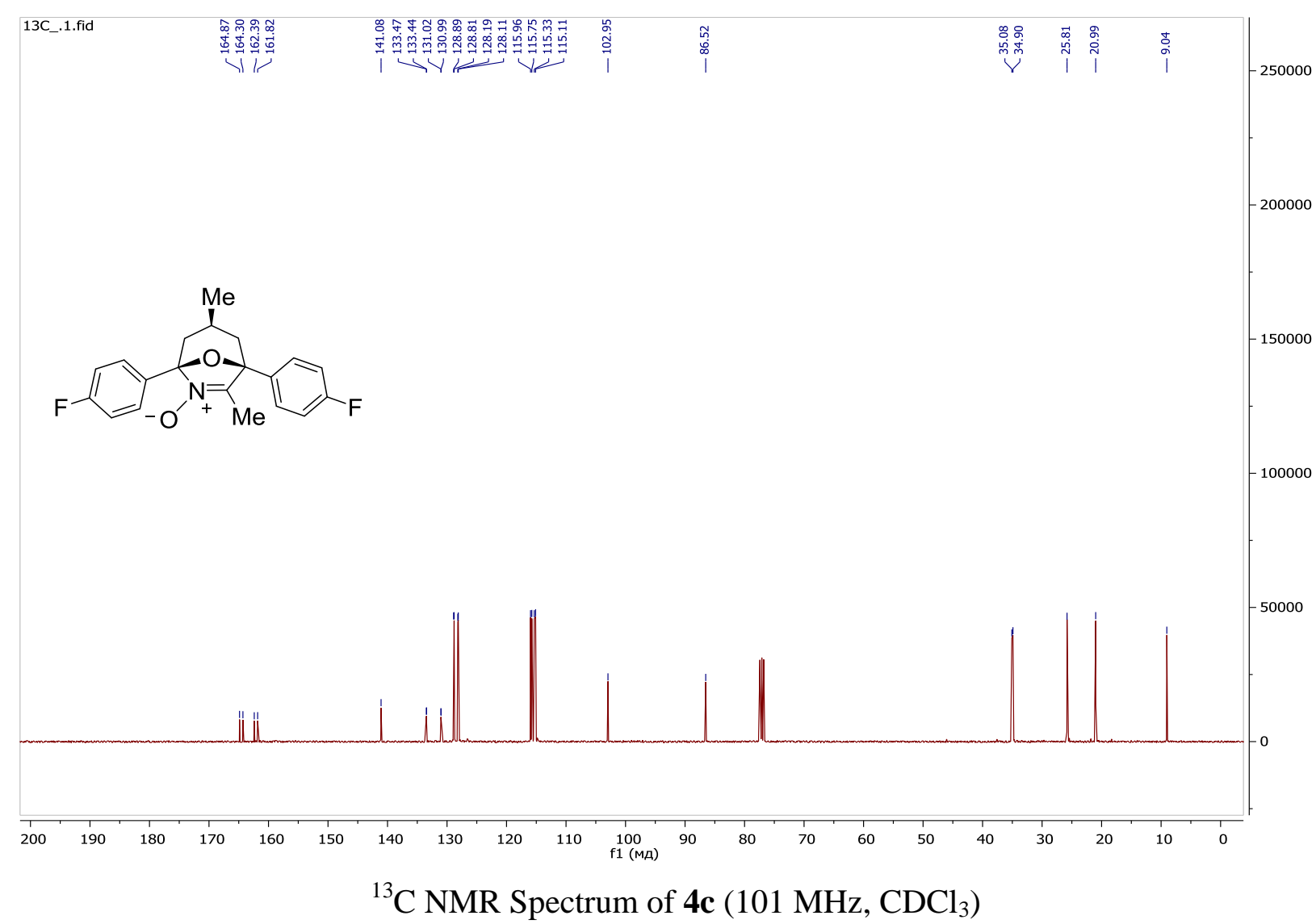




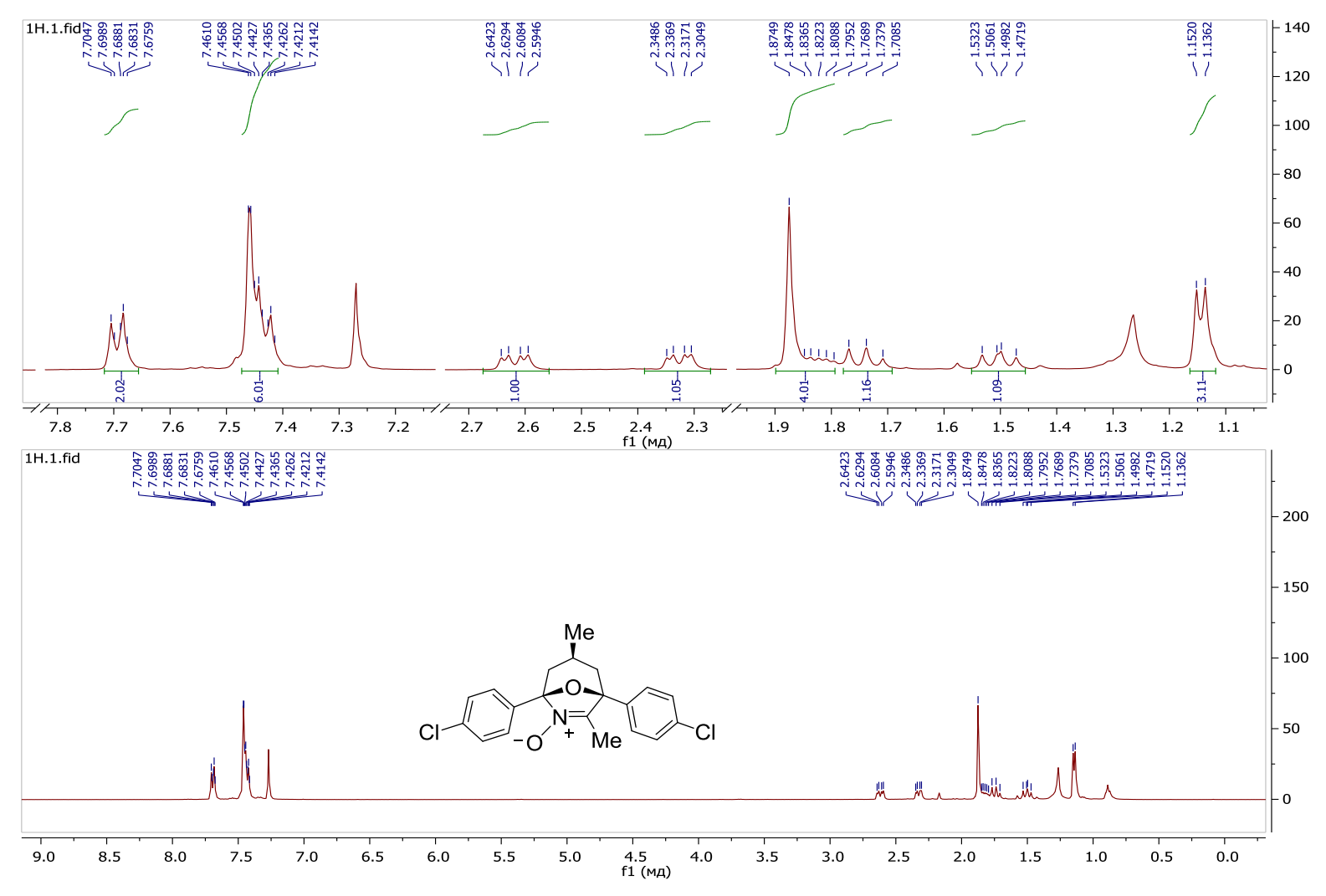

${ }^{1} \mathrm{H}$ NMR Spectrum of $\mathbf{4 d}\left(400 \mathrm{MHz}, \mathrm{CDCl}_{3}\right)$

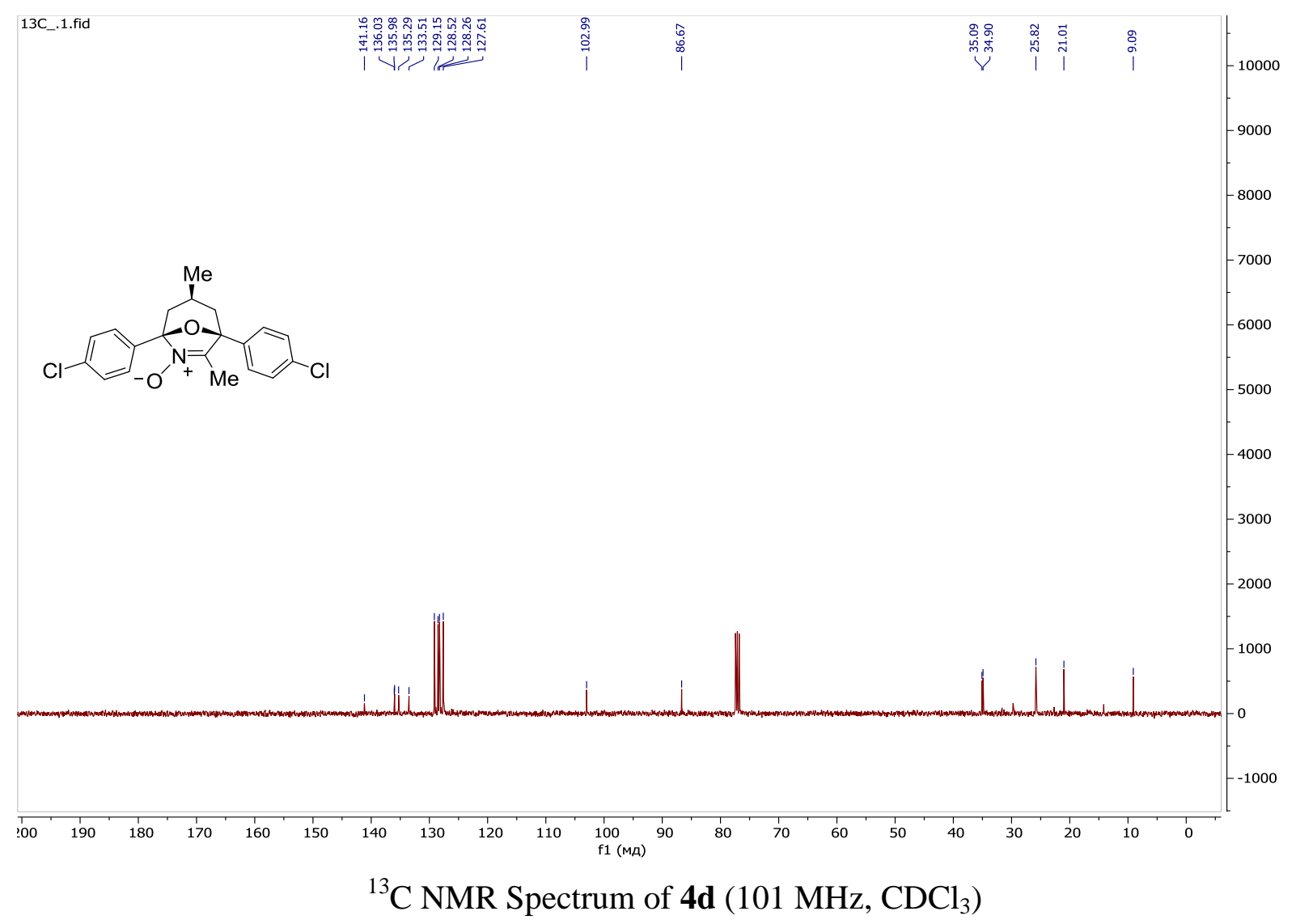




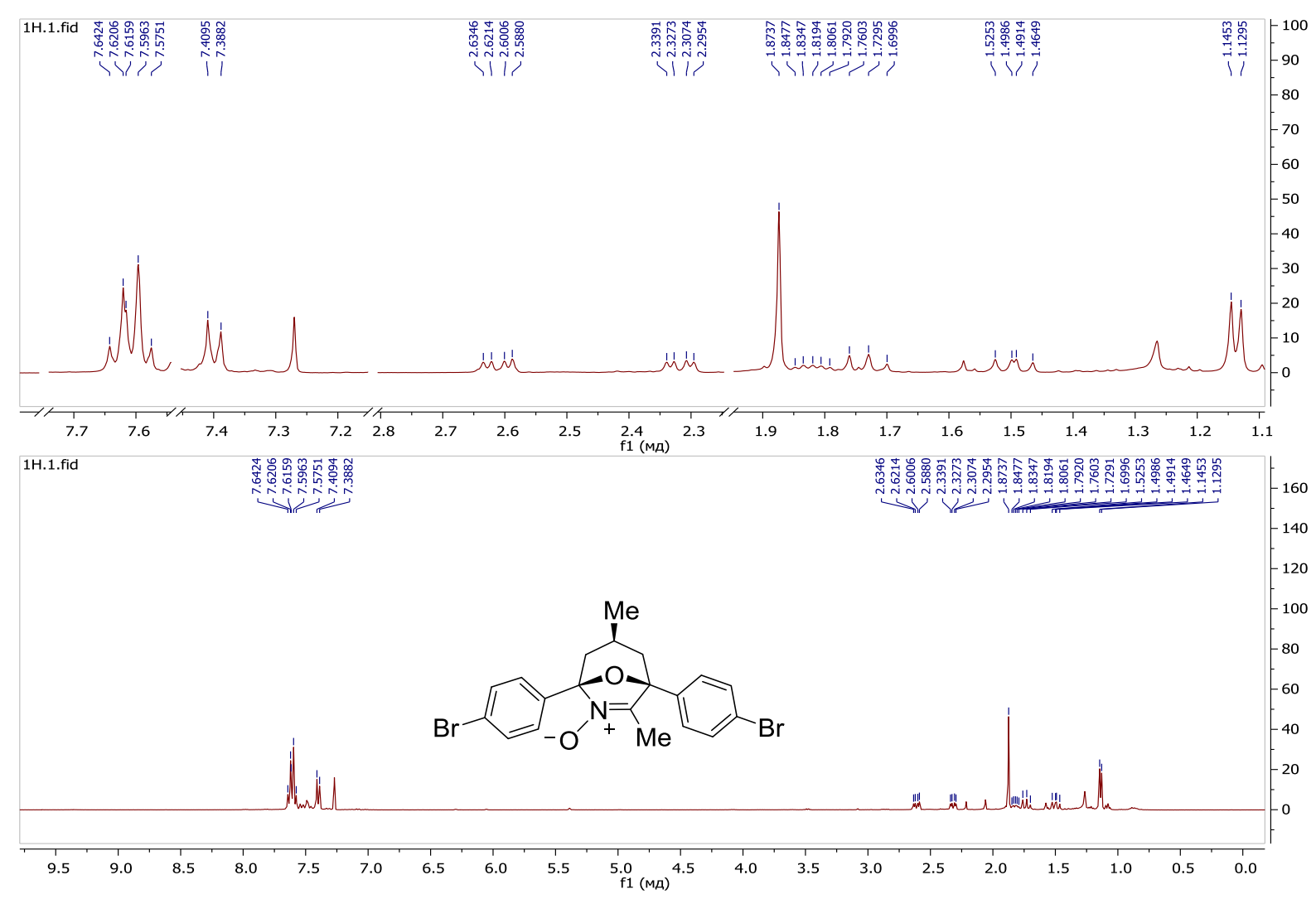

${ }^{1} \mathrm{H}$ NMR Spectrum of $\mathbf{4 e}\left(400 \mathrm{MHz}, \mathrm{CDCl}_{3}\right)$

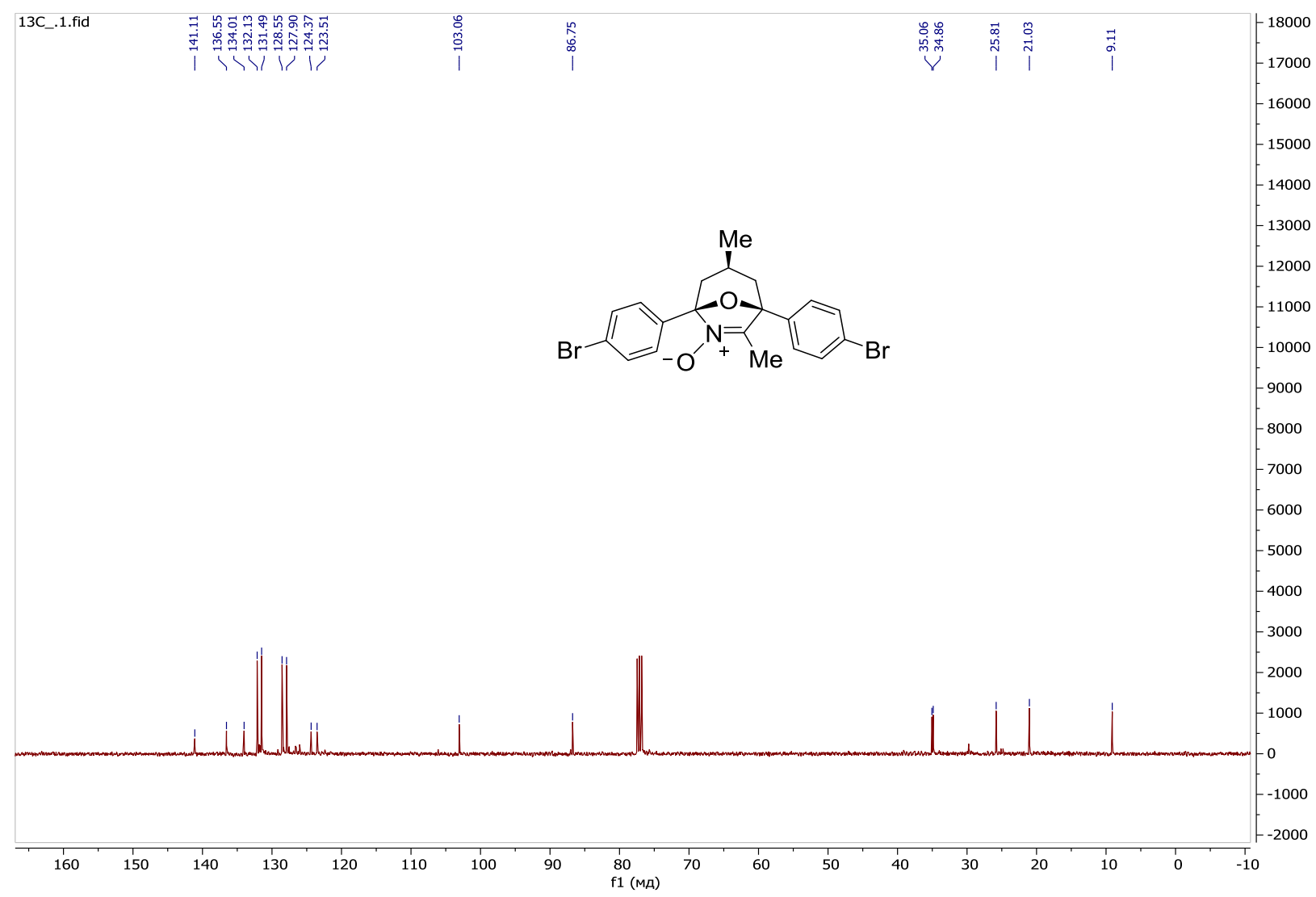

${ }^{13} \mathrm{C}$ NMR Spectrum of $\mathbf{4 e}\left(101 \mathrm{MHz}, \mathrm{CDCl}_{3}\right)$ 


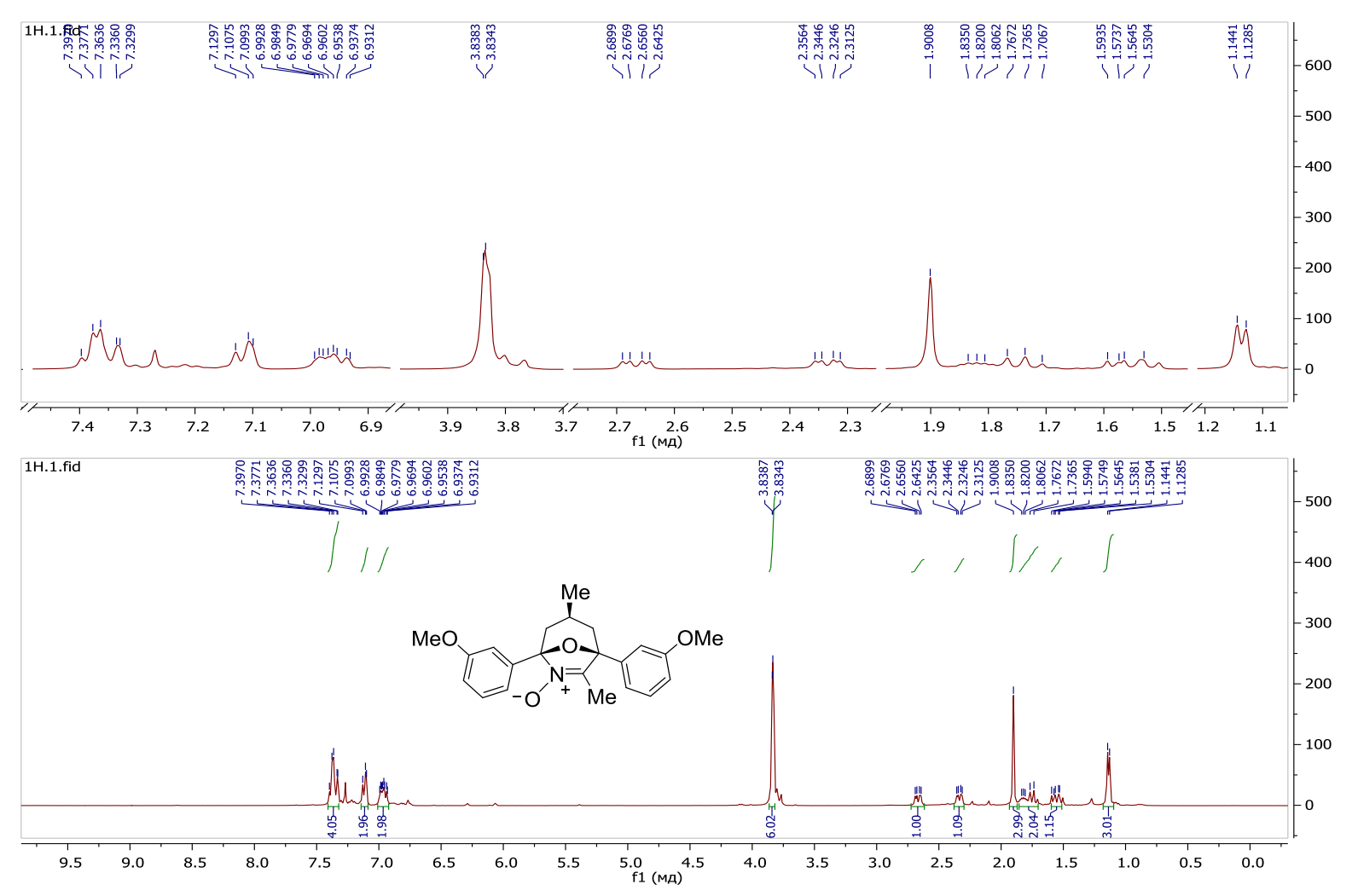

${ }^{1} \mathrm{H}$ NMR Spectrum of $\mathbf{4 f}\left(400 \mathrm{MHz}, \mathrm{CDCl}_{3}\right)$

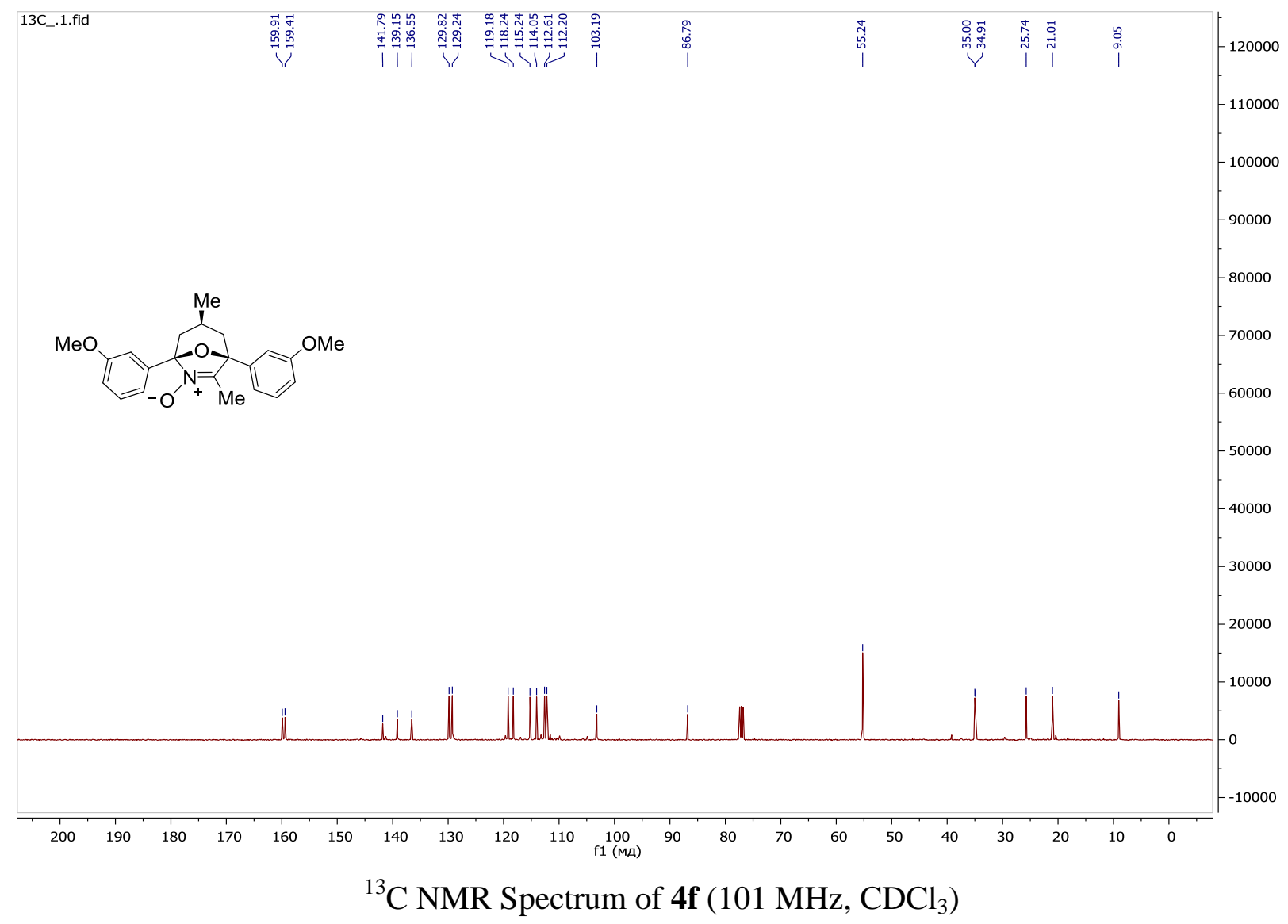




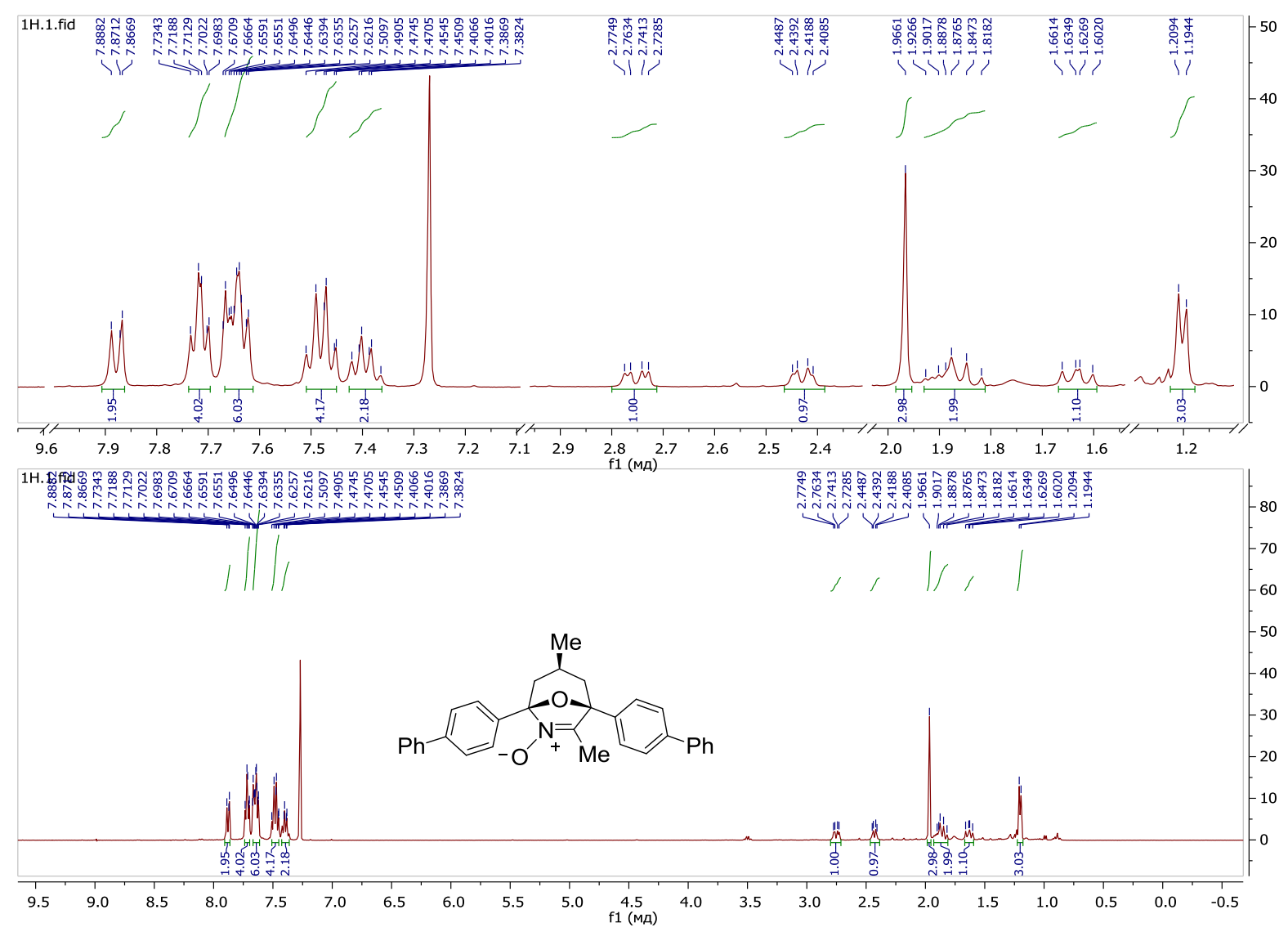

${ }^{1} \mathrm{H}$ NMR Spectrum of $\mathbf{4 g}\left(400 \mathrm{MHz}, \mathrm{CDCl}_{3}\right)$

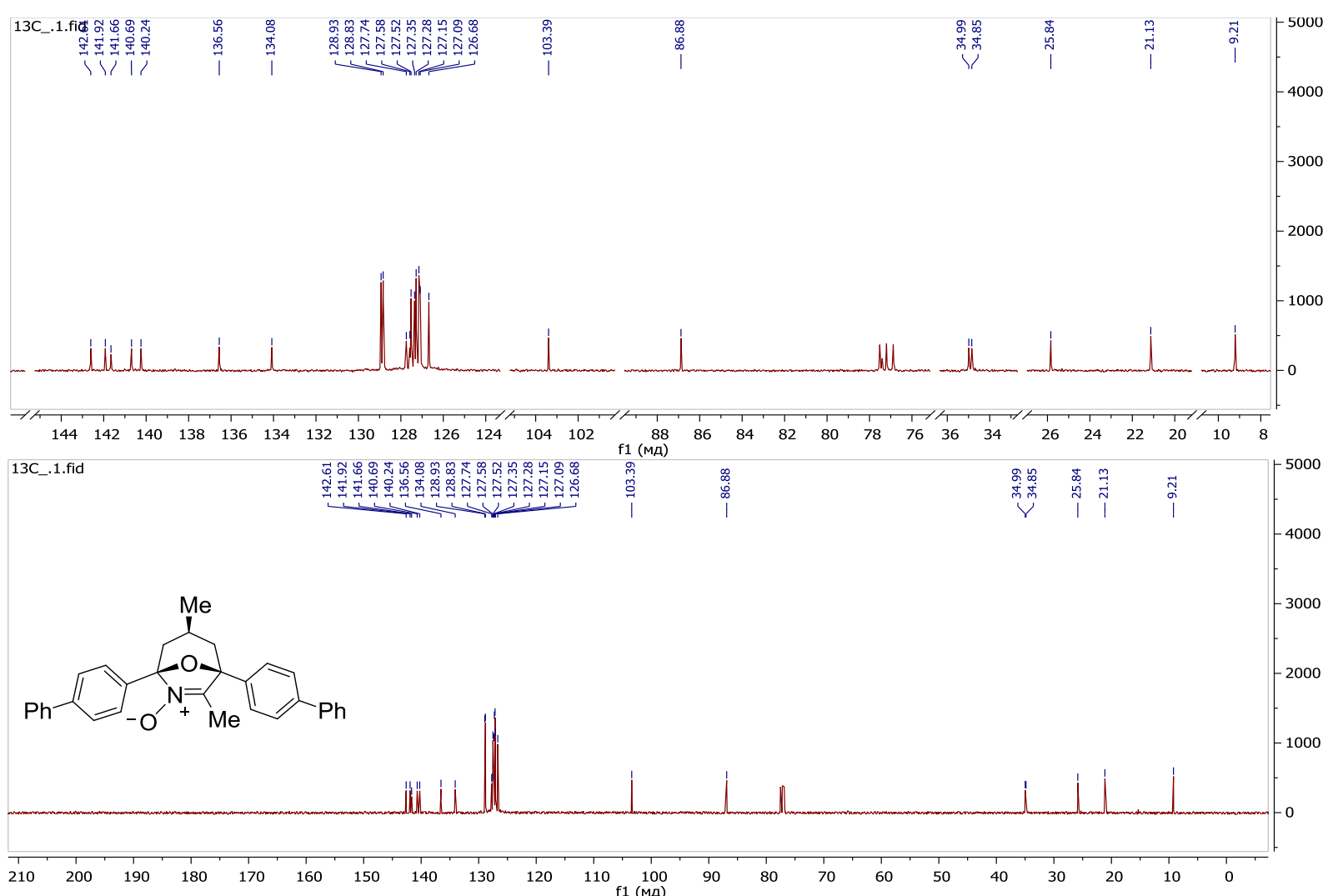

${ }^{13} \mathrm{C}$ NMR Spectrum of $\mathbf{4 g}\left(101 \mathrm{MHz}, \mathrm{CDCl}_{3}\right)$ 


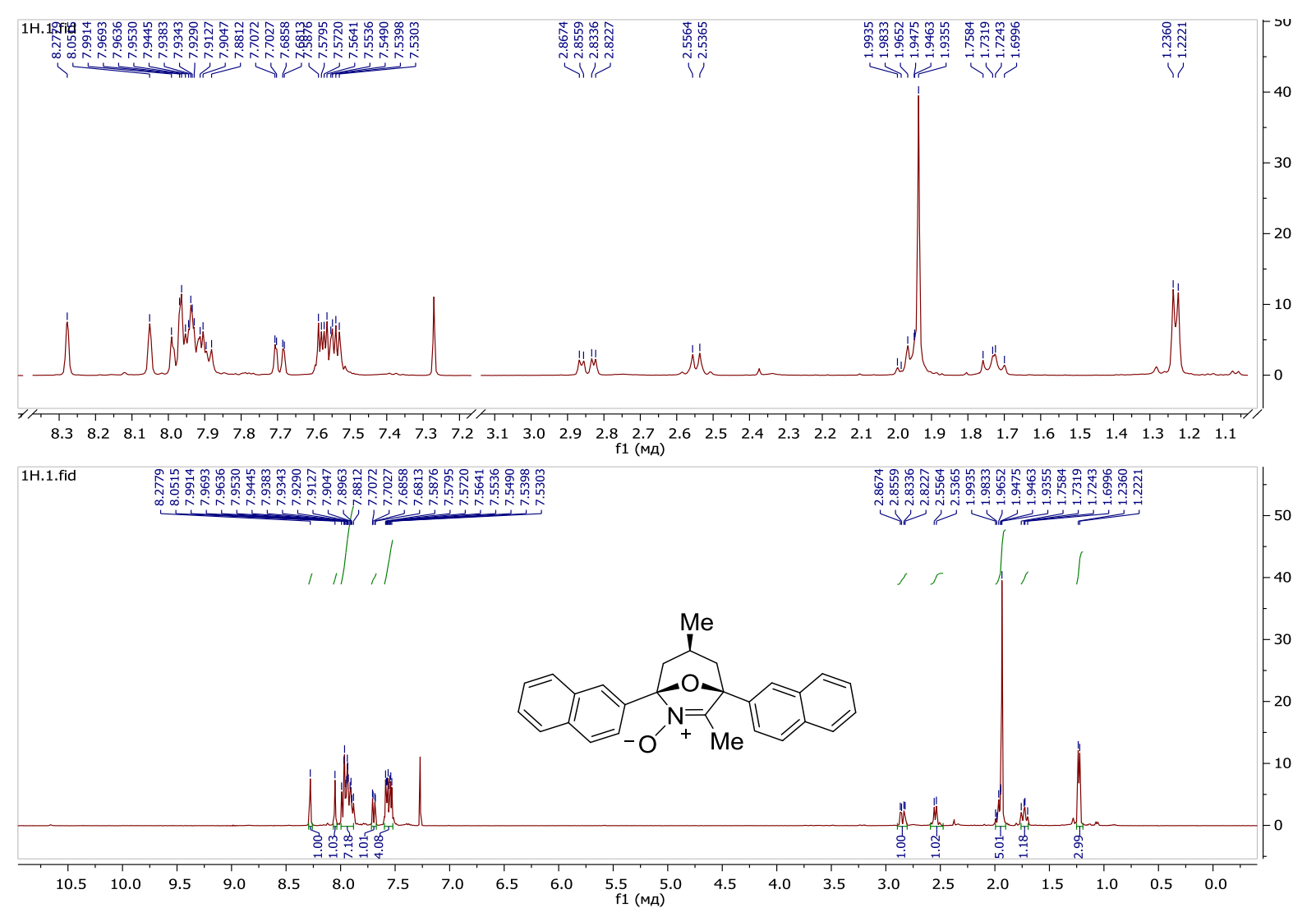

${ }^{1} \mathrm{H}$ NMR Spectrum of $\mathbf{4 h}\left(400 \mathrm{MHz}, \mathrm{CDCl}_{3}\right)$

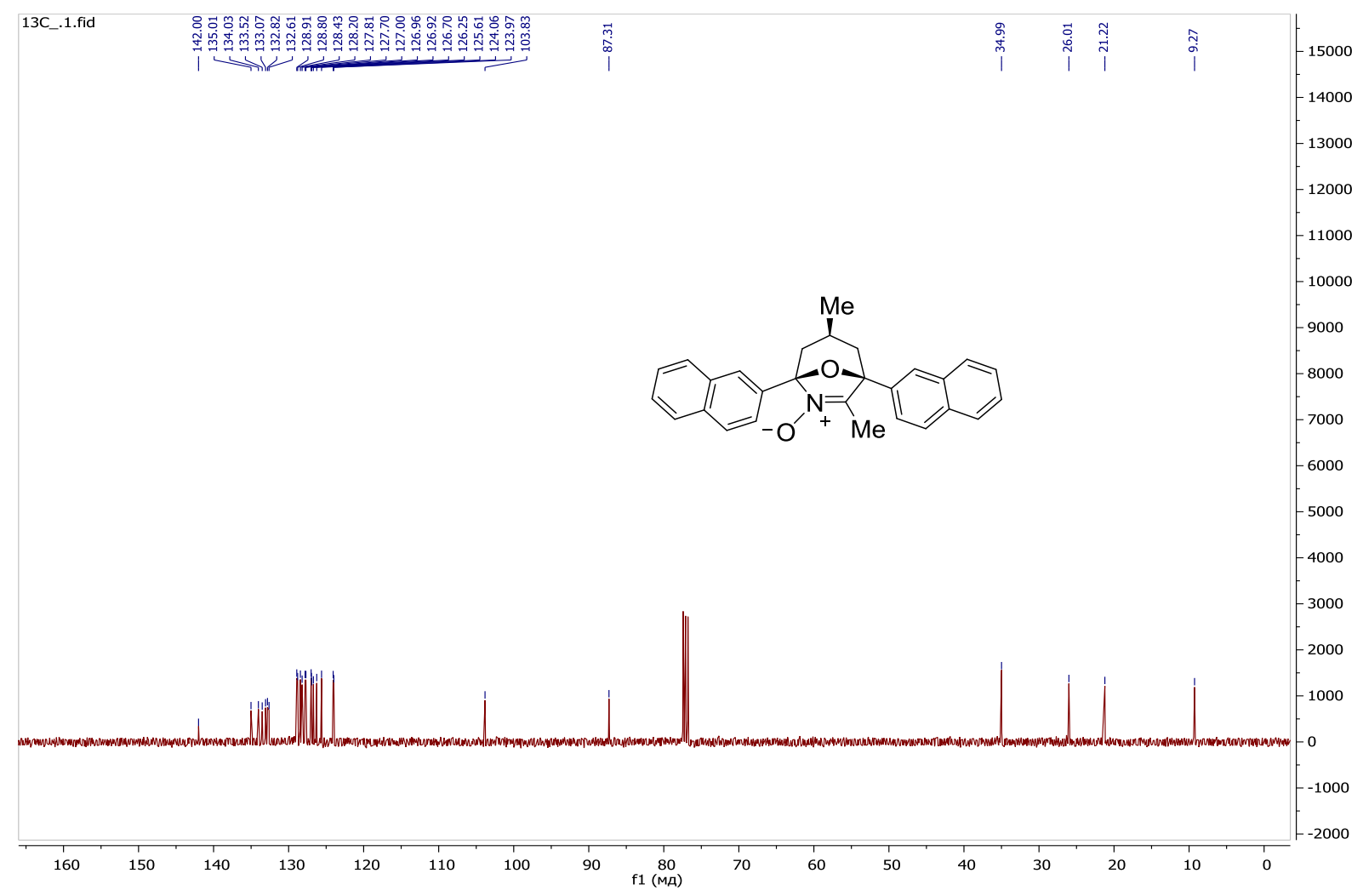

${ }^{13} \mathrm{C}$ NMR Spectrum of $\mathbf{4 h}\left(101 \mathrm{MHz}, \mathrm{CDCl}_{3}\right)$ 


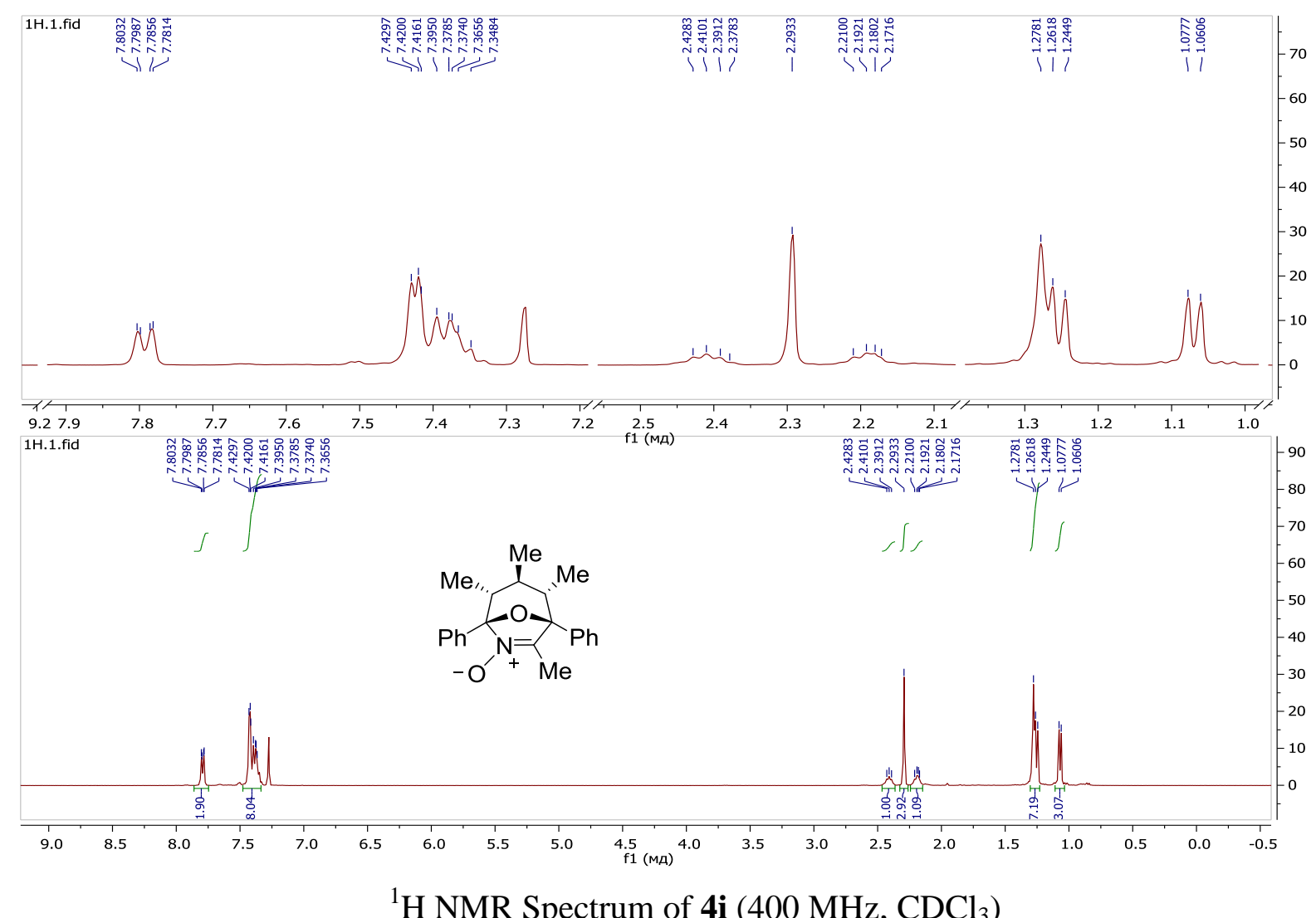

${ }^{1} \mathrm{H}$ NMR Spectrum of $4 \mathbf{i}\left(400 \mathrm{MHz}, \mathrm{CDCl}_{3}\right)$

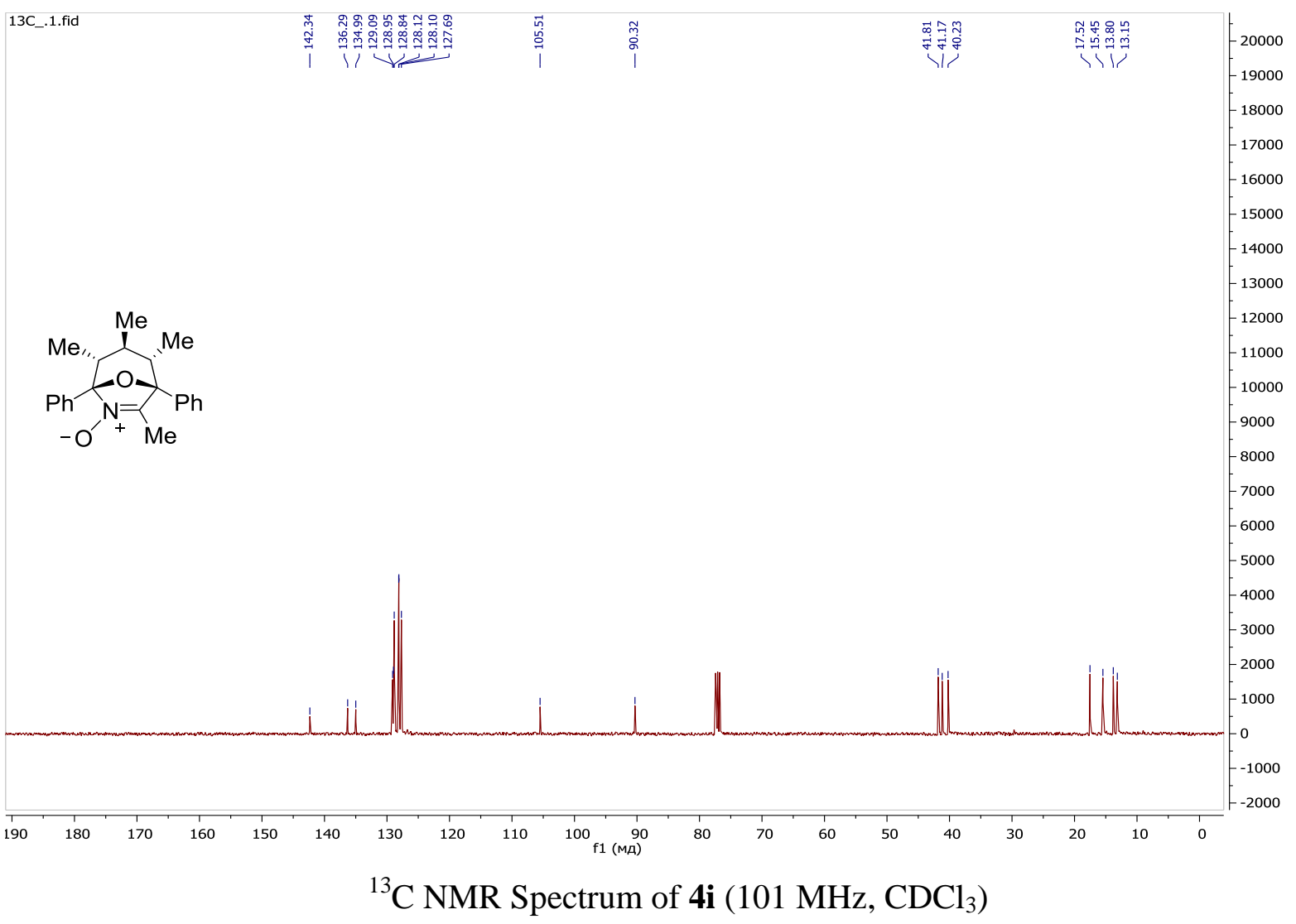




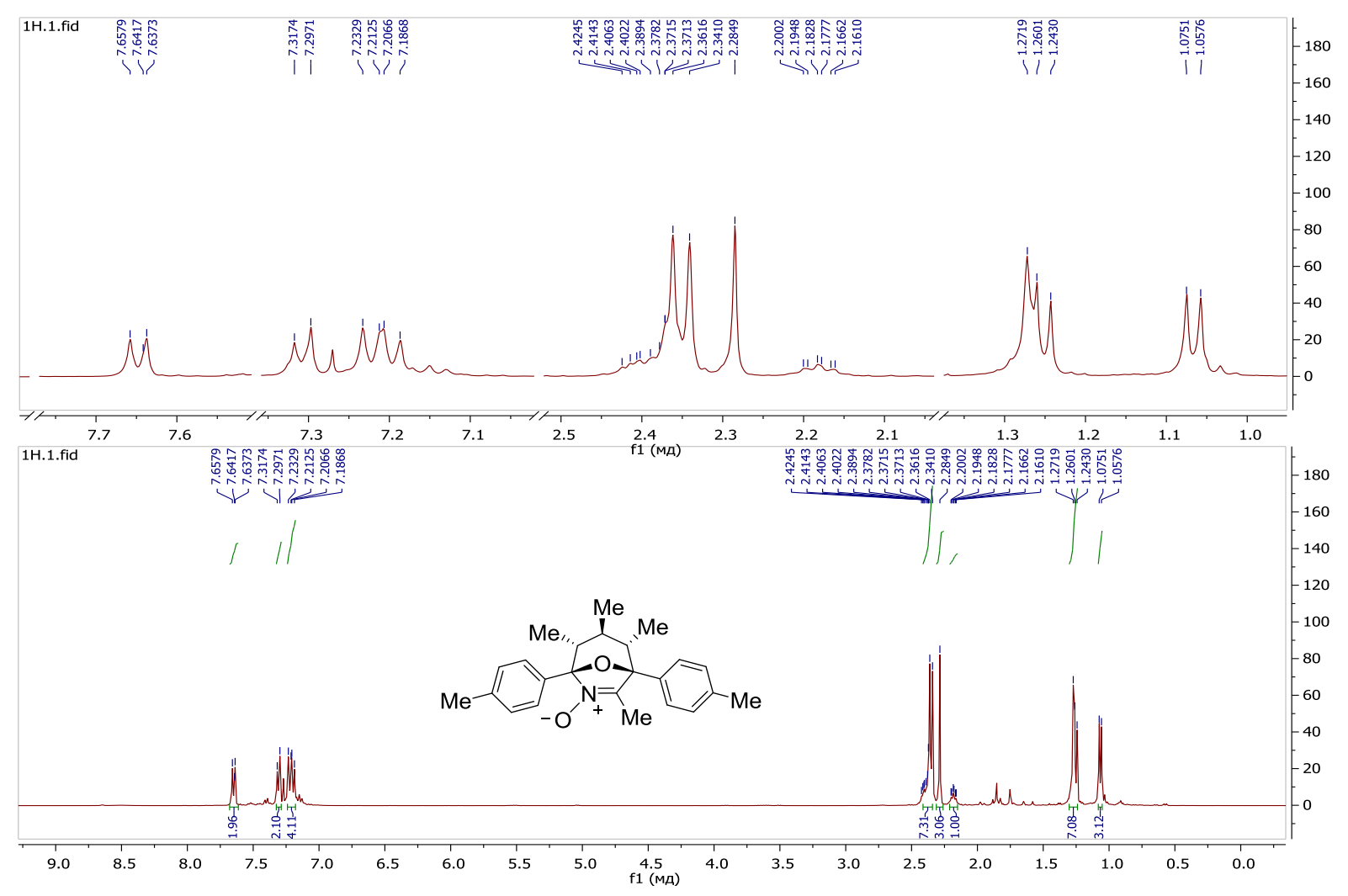

${ }^{1} \mathrm{H}$ NMR Spectrum of $\mathbf{4 j}$ (400 MHz, $\mathrm{CDCl}_{3}$ )

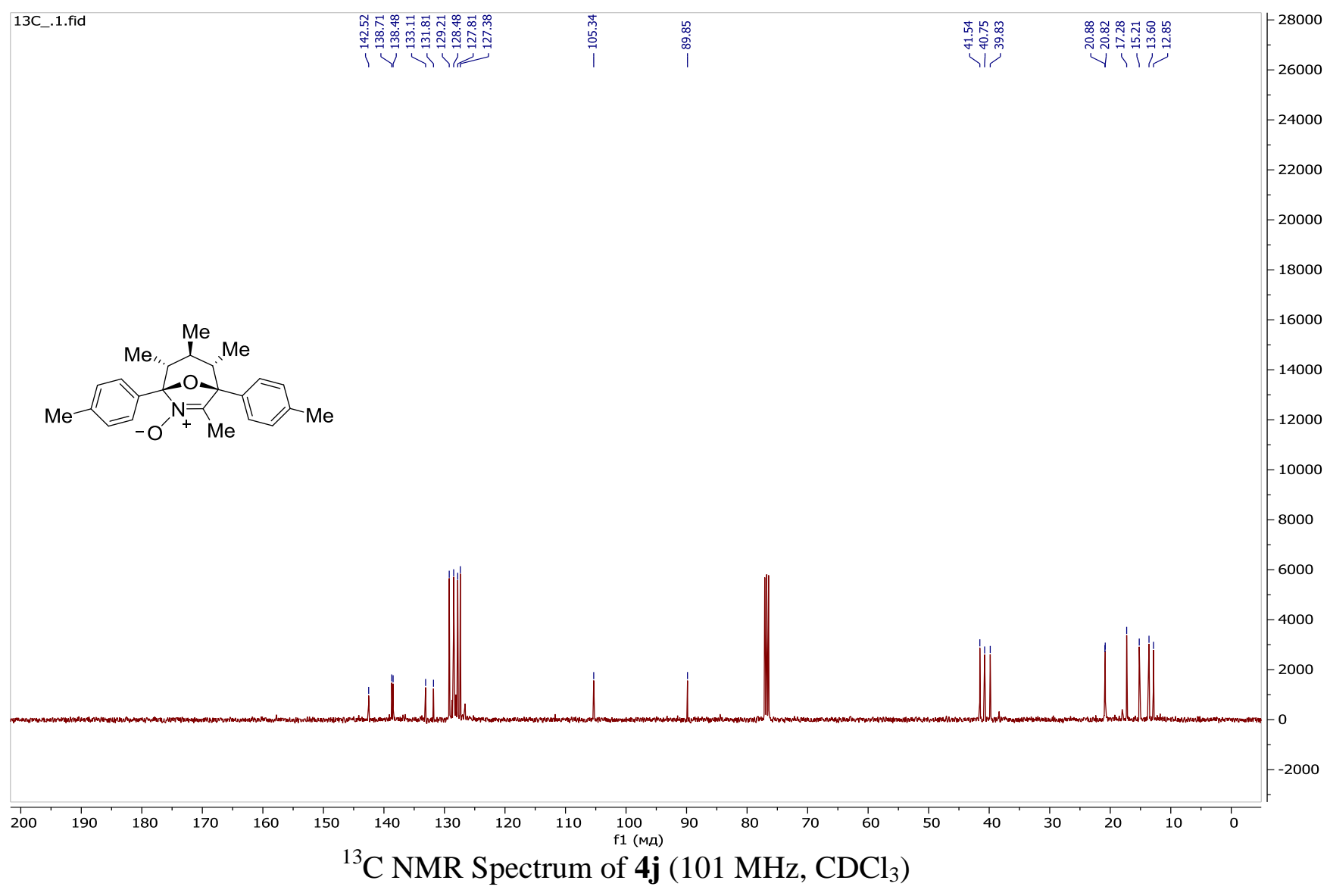




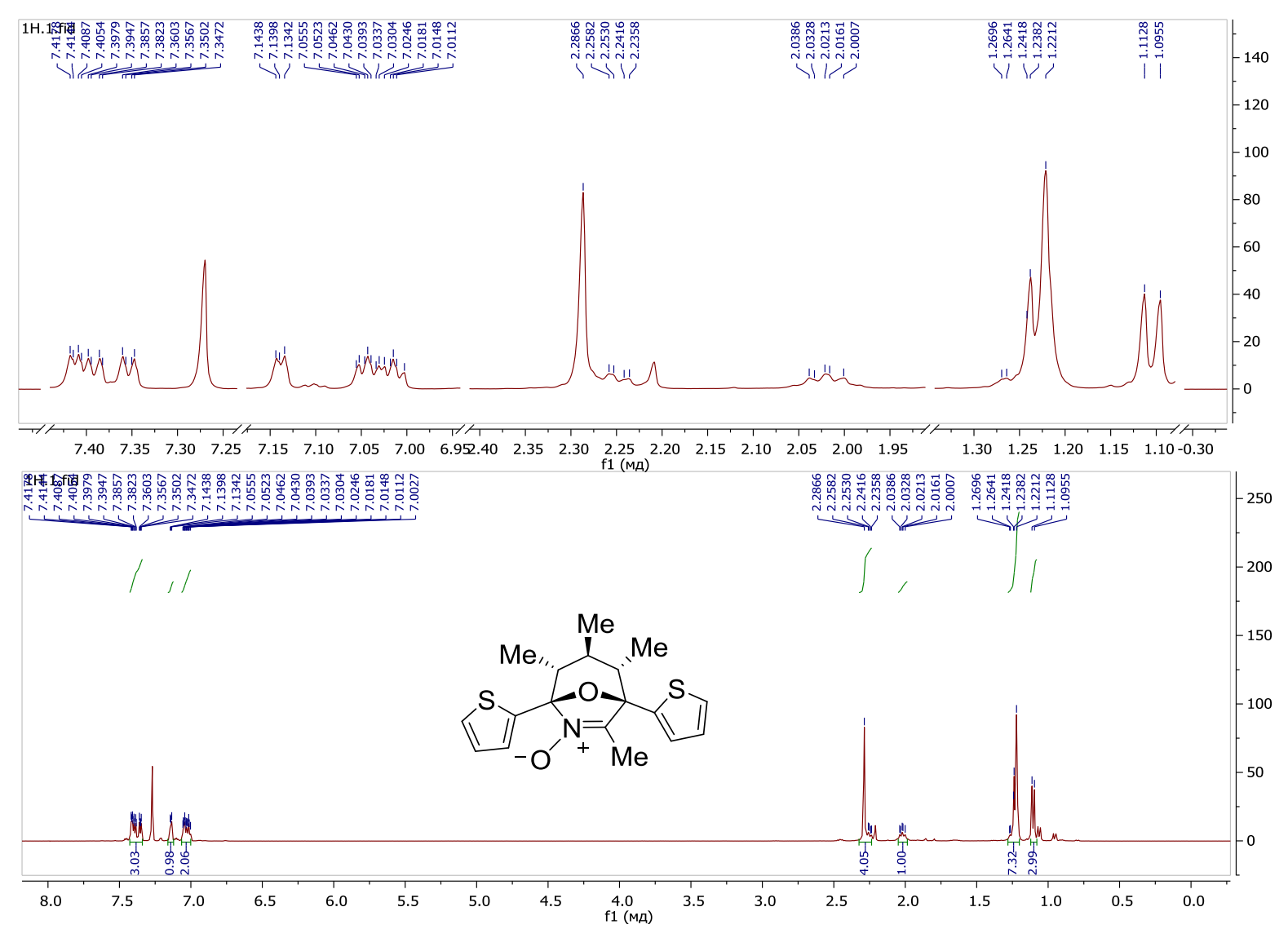

${ }^{1} \mathrm{H}$ NMR Spectrum of $\mathbf{4 k}\left(400 \mathrm{MHz}, \mathrm{CDCl}_{3}\right)$

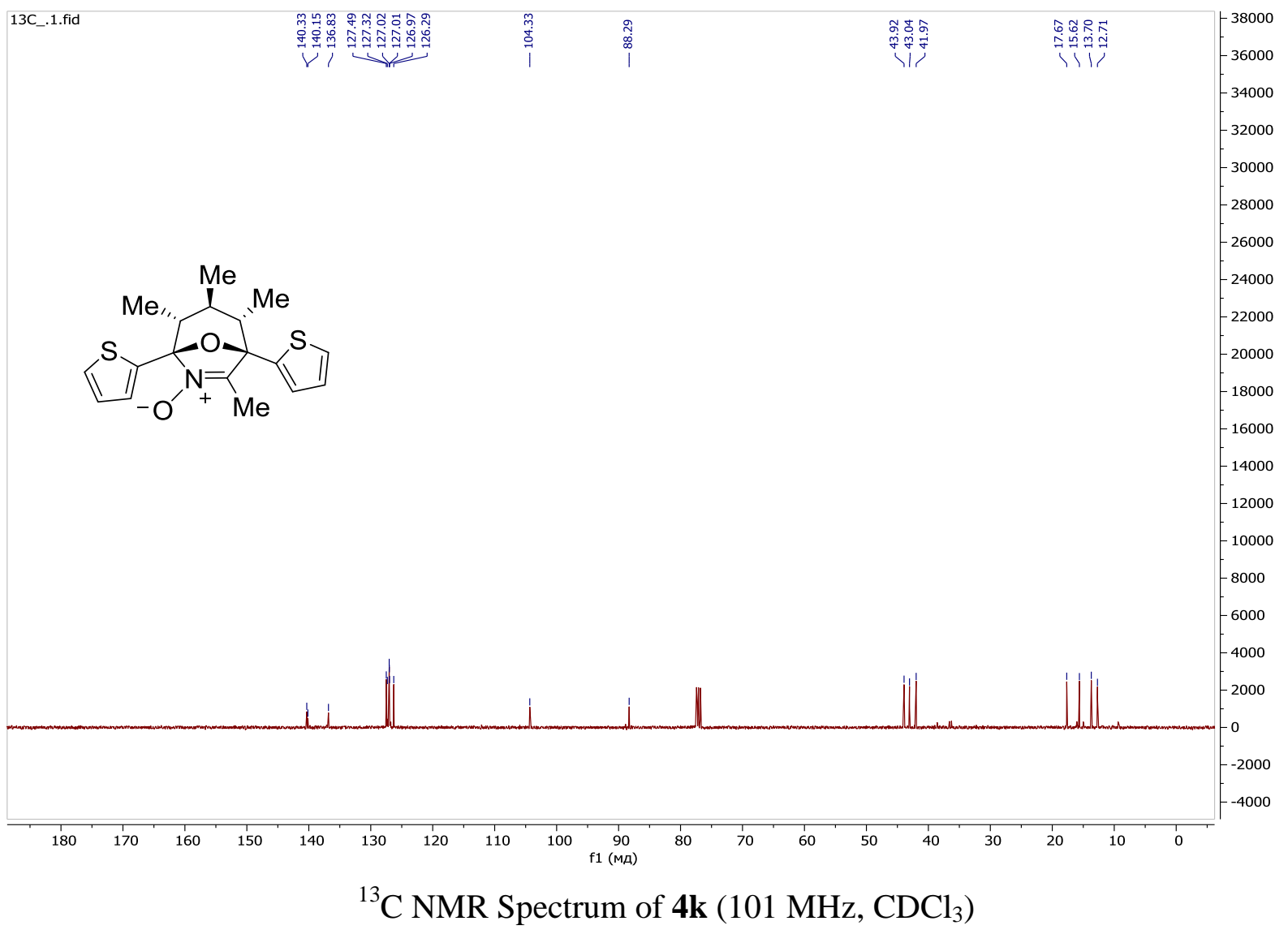



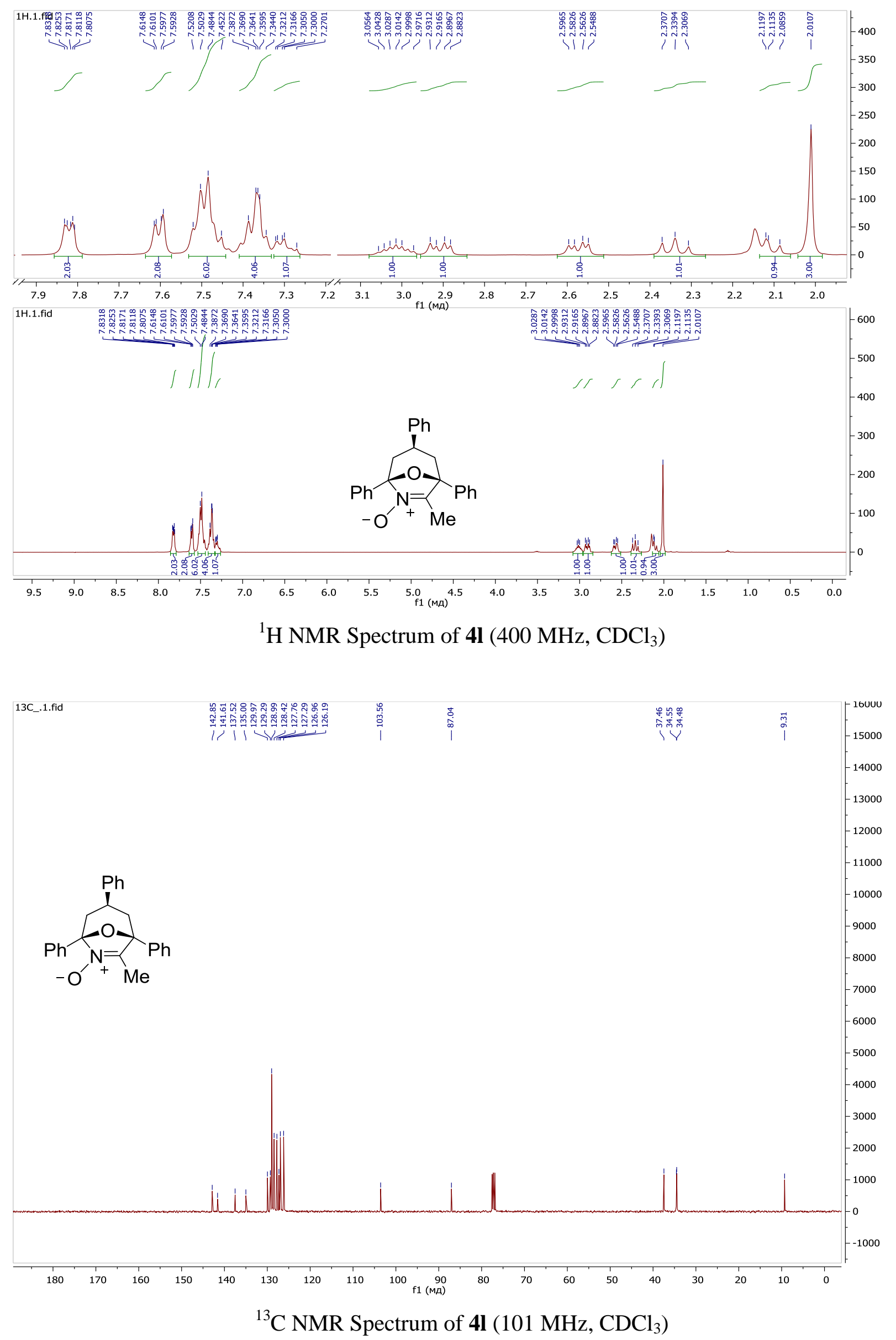


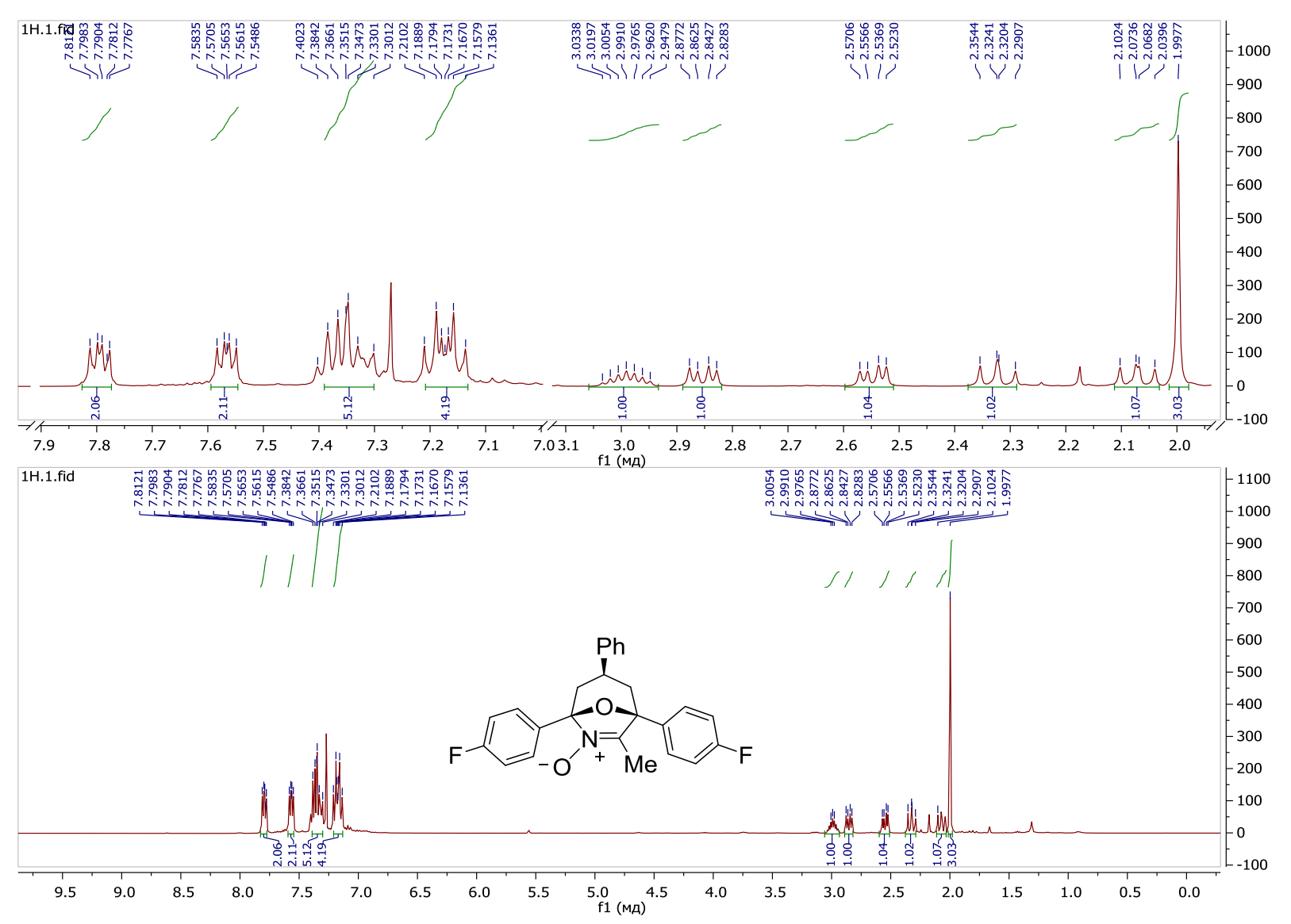

${ }^{1} \mathrm{H}$ NMR Spectrum of $\mathbf{4 m}\left(400 \mathrm{MHz}, \mathrm{CDCl}_{3}\right)$

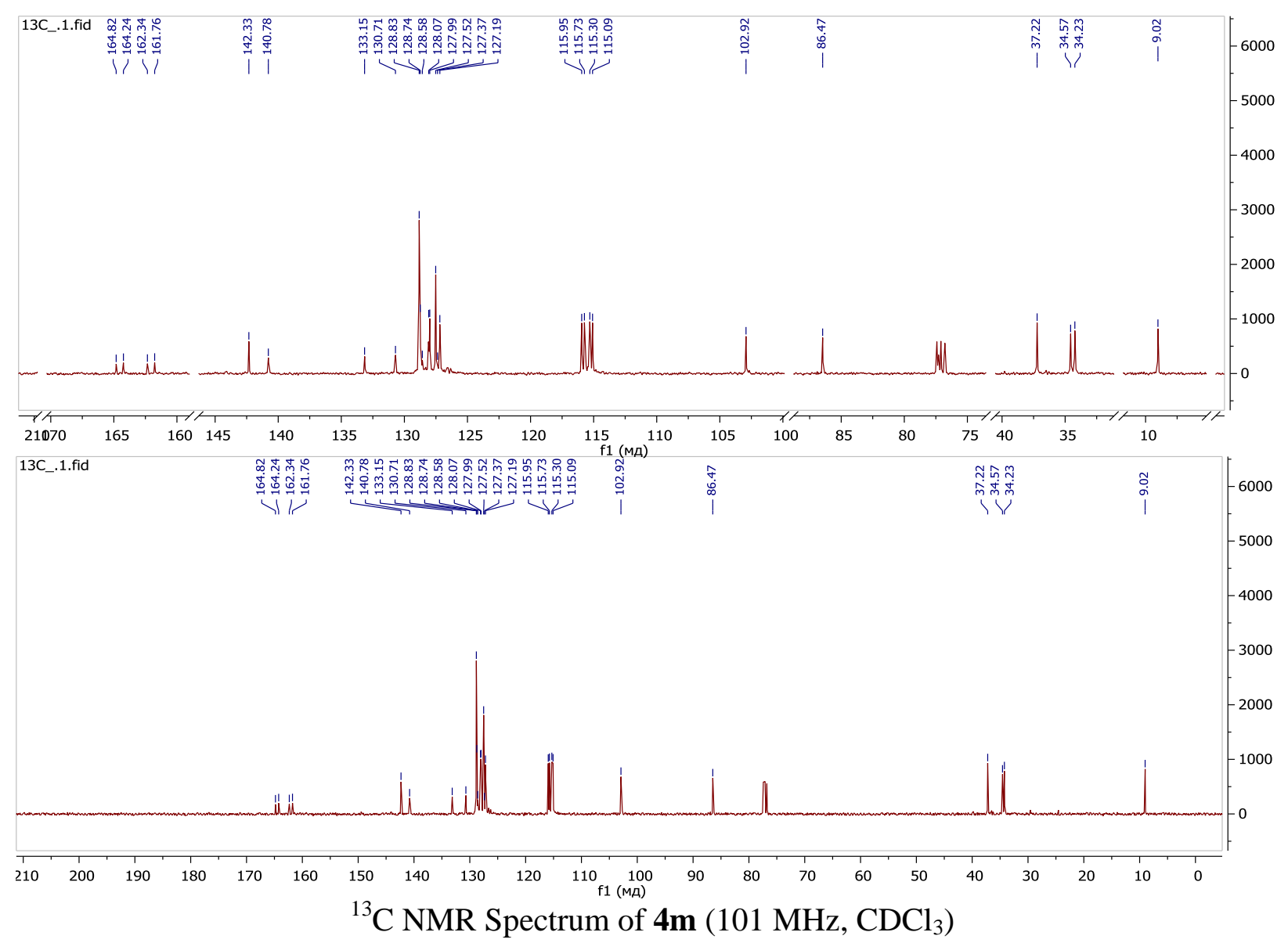




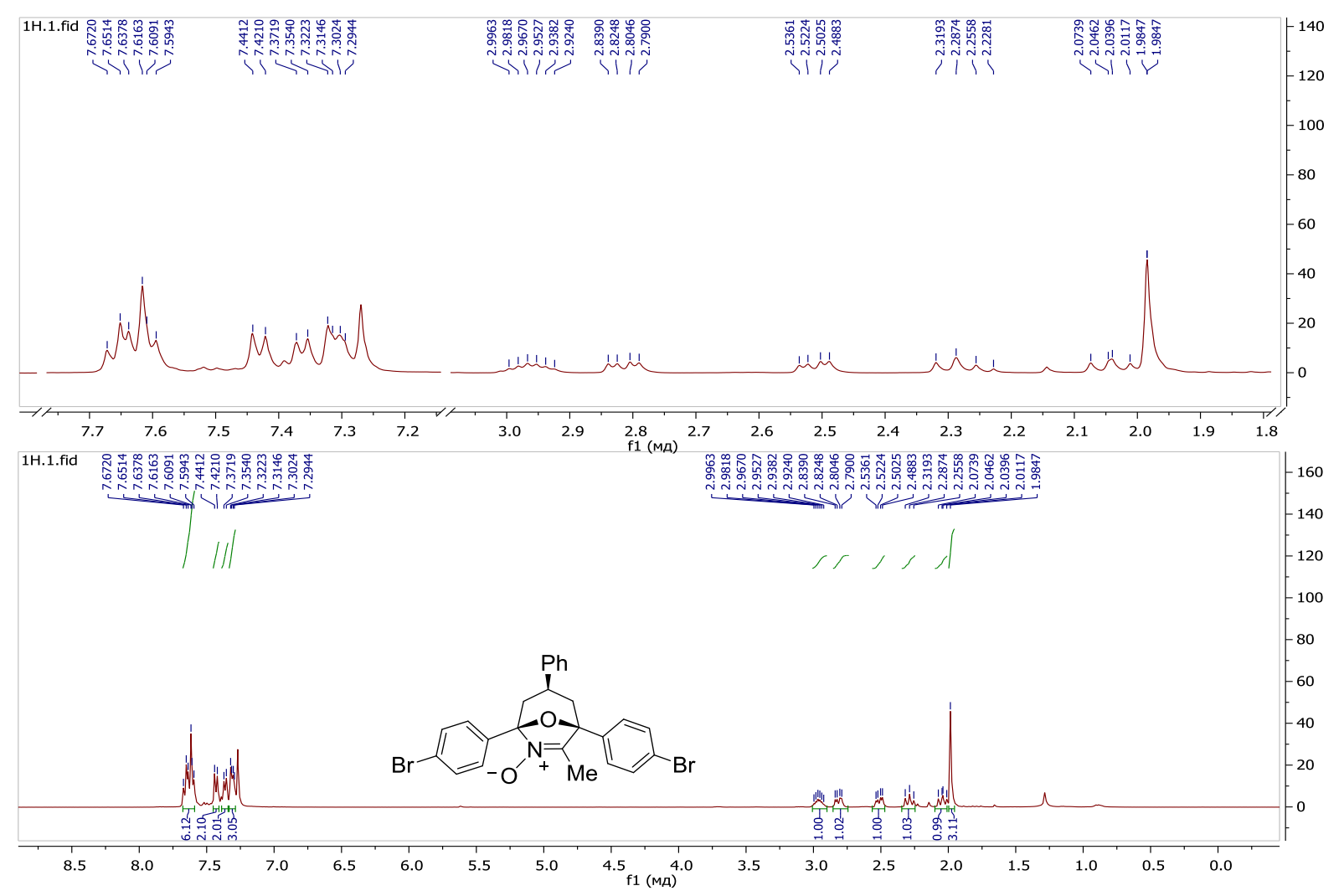

${ }^{1} \mathrm{H}$ NMR Spectrum of $\mathbf{4 n}\left(400 \mathrm{MHz}, \mathrm{CDCl}_{3}\right)$

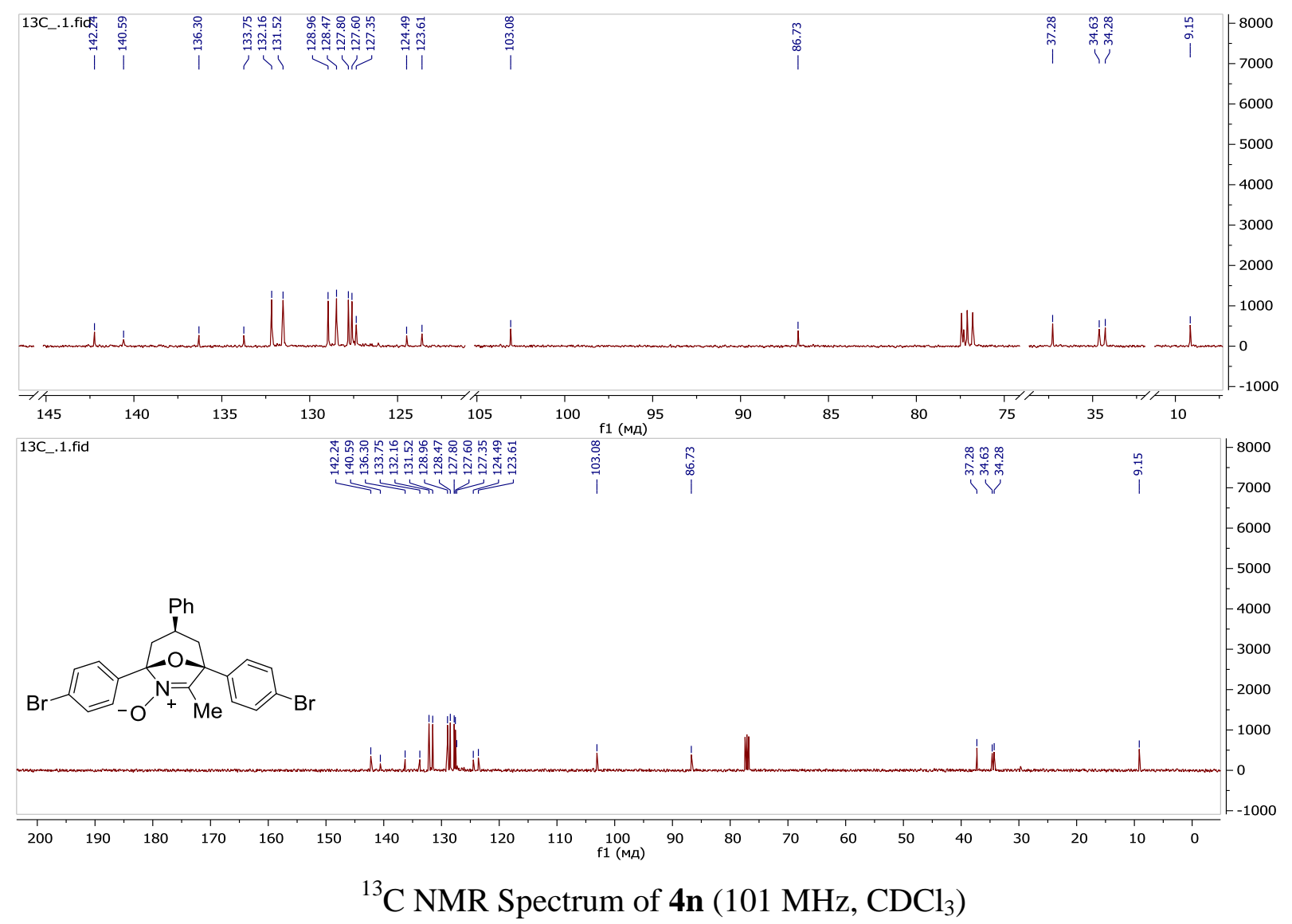




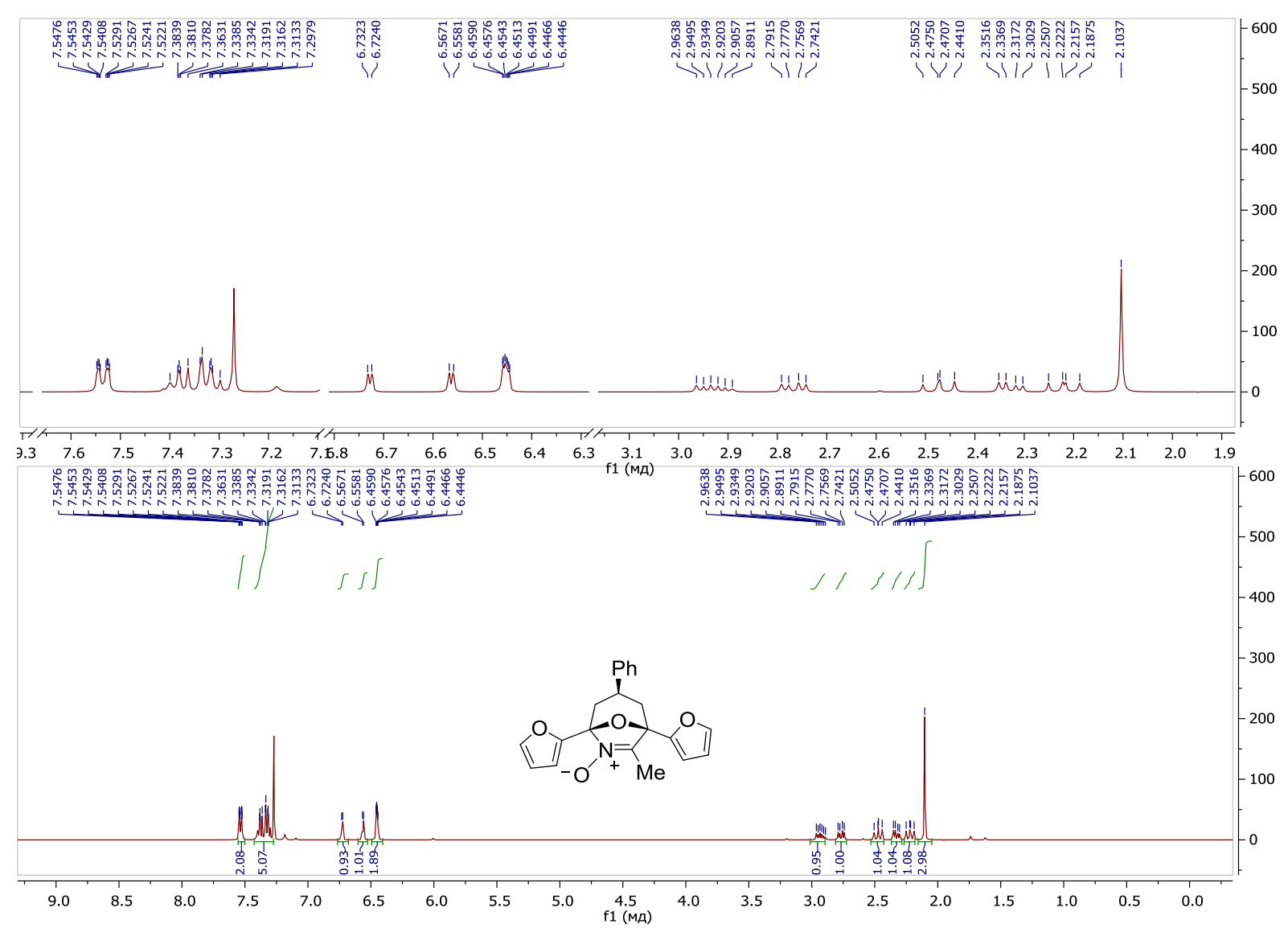

${ }^{1} \mathrm{H}$ NMR Spectrum of $4 \mathbf{o}\left(400 \mathrm{MHz}, \mathrm{CDCl}_{3}\right)$

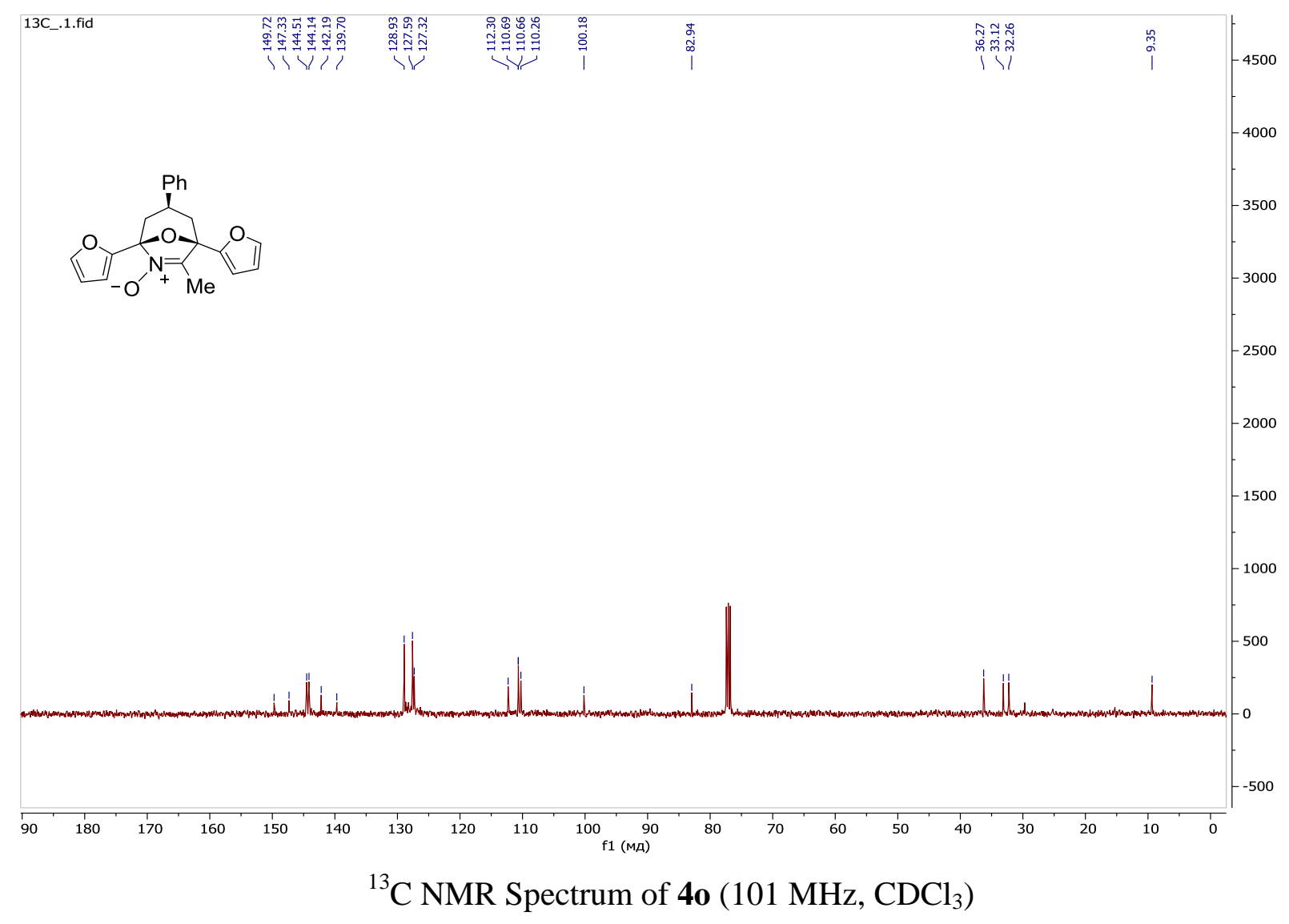




\section{X-Ray Diffraction Analysis}

Product 41 was dissolved in a large quantity ethyl ether and left to stand at $7-10{ }^{\circ} \mathrm{C}$ (refrigerator) in a septum-covered vial punctured with a needle. After roughly $24 \mathrm{~h}$, crystals began to precipitate as colorless prisms, which were filtered and dried in vacuo.

The determination of the unit cell and the data collection for $\left(1 R^{*}, 3 R^{*}, 5 S^{*}\right)-7$-methyl1,3,5-triphenyl-8-oxa-6-azabicyclo[3.2.1] oct-6-ene 6-oxide (4I) was performed on a Bruker D8 Venture Photon $100 \mathrm{CMOS}$ diffractometer with $\mathrm{MoK}_{\alpha}$ radiation $(\lambda=0.71073)$ at 297.0(2) $\mathrm{K}$ using the $\omega-\varphi$ scan technique. A specimen of $2\left(\mathrm{C}_{25} \mathrm{H}_{23} \mathrm{NO}_{2}\right) \cdot \mathrm{H}_{2} \mathrm{O}$, approximate dimensions 0.19 $\mathrm{mm} \times 0.19 \mathrm{~mm} \times 0.12 \mathrm{~mm}$, was used for the X-ray crystallographic analysis. The X-ray intensity data were measured. The integration of the data using a triclinic unit cell with $P$ - 1 space group yielded a total of 71221 reflections to a maximum $\theta$ angle of $24.3^{\circ}(0.81 \AA$ resolution $)$, of which 8164 were independent (completeness $=100 \%$, Rint $=5.71 \%$, Rsig $=4.78 \%$ ) and 5200 were greater than $2 \sigma(\mathrm{F} 2)$. The final cell constants of $\mathbf{a}=10.384(8) \AA, \mathbf{b}=10.986(8) \AA, \mathbf{c}=19.425(14)$ $\AA, Z=2, \alpha=102.72(2)^{\circ}, \beta=92.22(4)^{\circ}, \gamma=109.91(3)^{\circ}$, Volume $=2017(3) \AA^{3}$. Data were corrected for absorption effects using the multi-scan method (SADABS). The ratio of minimum to maximum apparent transmission was 0.922. The structure was solved and refined using the Bruker SHELXTL Software Package. ${ }^{2}$ The $\mathrm{H}$ atoms were determined by rider method.

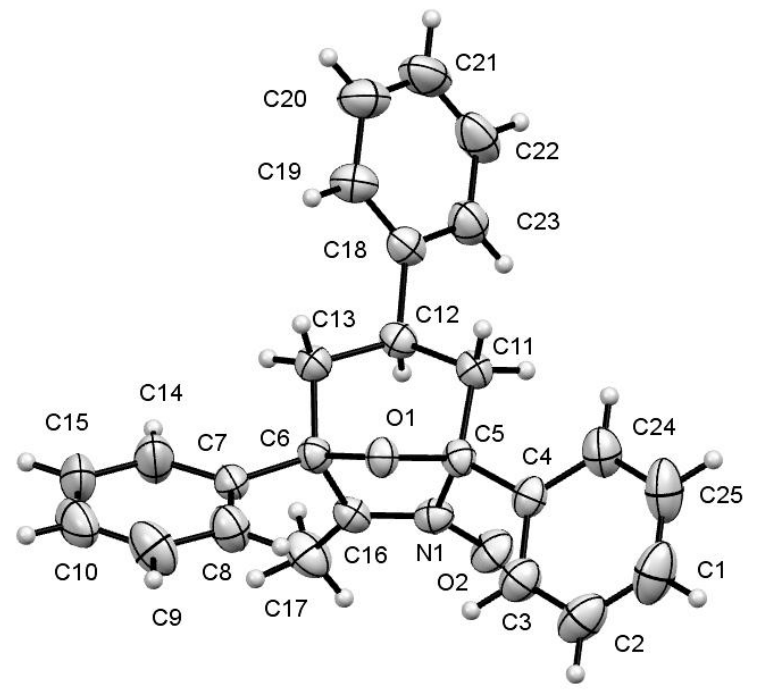

Figure S1. X-Ray Structure of $\left(1 R^{*}, 3 R^{*}, 5 S^{*}\right)$-7-Methyl-1,3,5-triphenyl-8-oxa-6azabicyclo[3.2.1] oct-6-ene 6-oxide (41). Thermal ellipsoids set at 50\% probability.

The final anisotropic full-matrix least-squares refinement on $\mathrm{F}^{2}$ with 519 variables converged at $\mathrm{R} 1=5.39 \%$, for the observed data and $\mathrm{wR} 2=13.09 \%$ for all data. The goodnessof-fit was 1.06. The highest peak in the final difference electron density synthesis was 0.190 e- 
$/ \AA^{3}$ and the deepest hole was $-0.22 \mathrm{e}-/ \AA^{3}$. On the basis of the final model, the calculated density was $1.246 \mathrm{~g} / \mathrm{cm}^{3}$ and $\mathrm{F}(000), 804 \mathrm{e}-$.

Table S1. X-Ray Structure Report of 41

\begin{tabular}{|c|c|c|}
\hline $\begin{array}{l}\text { Bond precision: } \\
\text { Cell: } \mathrm{a}=10.384(8) \\
\text { alpha }=1 \underline{0} 2.72(2)\end{array}$ & $\begin{array}{c}\mathrm{C}-\mathrm{C}=0.0037 \AA \\
\mathrm{b}=10.986(8) \\
\operatorname{beta}^{2} \underline{92.22(4)^{\circ}}\end{array}$ & $\begin{array}{l}\text { Wavelength }=0.71073 \AA \\
\mathrm{c}=19.425(14) \\
\text { gamma }=109.91(3)^{\circ}\end{array}$ \\
\hline \multicolumn{3}{|c|}{ Temperature: $293 \mathrm{~K}$} \\
\hline & Calculated & Reported \\
\hline Volume & $2017(3)$ & 2017(3) \\
\hline Space group & $P-1$ & $\mathrm{P}-1$ \\
\hline Hall group & $-\mathrm{P} 1$ & $-\mathrm{P} 1$ \\
\hline Moiety formula & $2(\mathrm{C} 25 \mathrm{H} 23 \mathrm{~N} \mathrm{O} 2), \mathrm{H} 2 \mathrm{O}$ & 2(C25 H23 N O2), H2O \\
\hline Sum formula & $\mathrm{C} 50 \mathrm{H} 48 \mathrm{~N} 2 \mathrm{O} 5$ & $\mathrm{C} 50 \mathrm{H} 48 \mathrm{~N} 2 \mathrm{O} 5$ \\
\hline $\mathrm{Mr}$ & 756.90 & 756.90 \\
\hline Dx,g cm-3 & 1.246 & 1.246 \\
\hline $\mathrm{Z}$ & 2 & 2 \\
\hline $\mathrm{Mu}(\mathrm{mm}-1)$ & 0.080 & 0.080 \\
\hline F000 & 804.0 & 804.0 \\
\hline F000’ & 804.35 & \\
\hline $\mathrm{h}, \mathrm{k}, \operatorname{lmax}$ & $13,14,24$ & $12,13,24$ \\
\hline Nref & 8970 & 8164 \\
\hline Tmin,Tmax & $0.985,0.990$ & $0.985,0.990$ \\
\hline Tmin' & 0.985 & \\
\hline \multicolumn{3}{|c|}{ AbsCorr $=$ MULTI-SCAN } \\
\hline \multicolumn{2}{|c|}{ Data completeness $=0.910$} & $\operatorname{Theta}(\max )=27.170$ \\
\hline \multicolumn{2}{|c|}{$\mathrm{R}($ reflections $)=0.0539(5200)$} & $\mathrm{wR} 2($ reflections $)=0.1309(8164$ \\
\hline \multicolumn{2}{|l|}{$S=1.060$} & Npar $=519$ \\
\hline
\end{tabular}

Atomic coordinates, bond lengths, bond angles and thermal parameters have been deposited at the Cambridge Crystallographic Data Centre (CCDC) and allocated the deposition numbers CCDC 1981451. These data can be obtained free of charge from the Cambridge Crystallographic Data Centre via www.ccdc.cam.ac.uk/data_request/cif.

\section{References}

(1) Sheldrick, G.M. Acta Crystallogr. 2008, D64, 112-122. 